\title{
(a/A)rchitecture? A Participatory Experiment
}

by

\author{
Lee Bushey
}

A thesis submitted to the Faculty of Graduate and Postdoctoral Affairs in partial fulfillment of the requirements for the degree of

Master of Architecture

in

Architectural Studies

Carleton University

Ottawa, Ontario

(C) 2012

Lee Bushey 
Library and Archives

Canada

Published Heritage

Branch

395 Wellington Street

Ottawa ON K1A ON4

Canada
Bibliothèque et

Archives Canada

Direction du

Patrimoine de l'édition

395 , rue Wellington

Ottawa ON K1A ON4

Canada
Your file Votre référence

ISBN: 978-0-494-91514-1

Our file Notre référence

ISBN: 978-0-494-91514-1
NOTICE:

The author has granted a nonexclusive license allowing Library and Archives Canada to reproduce, publish, archive, preserve, conserve, communicate to the public by telecommunication or on the Internet, loan, distrbute and sell theses worldwide, for commercial or noncommercial purposes, in microform, paper, electronic and/or any other formats.

The author retains copyright ownership and moral rights in this thesis. Neither the thesis nor substantial extracts from it may be printed or otherwise reproduced without the author's permission.
AVIS:

L'auteur a accordé une licence non exclusive permettant à la Bibliothèque et Archives Canada de reproduire, publier, archiver, sauvegarder, conserver, transmettre au public par télécommunication ou par l'Internet, prêter, distribuer et vendre des thèses partout dans le monde, à des fins commerciales ou autres, sur support microforme, papier, électronique et/ou autres formats.

L'auteur conserve la propriété du droit d'auteur et des droits moraux qui protege cette thèse. $\mathrm{Ni}$ la thèse ni des extraits substantiels de celle-ci ne doivent être imprimés ou autrement reproduits sans son autorisation.
In compliance with the Canadian Privacy Act some supporting forms may have been removed from this thesis.

While these forms may be included in the document page count, their removal does not represent any loss of content from the thesis.
Conformément à la loi canadienne sur la protection de la vie privée, quelques formulaires secondaires ont été enlevés de cette thèse.

Bien que ces formulaires aient inclus dans la pagination, il n'y aura aucun contenu manquant. 


\begin{abstract}
This thesis investigates the role of the architect as a facilitator with the end user in the design-build process. Two practical case studies (involving the design and construction of two small structures with local community groups) are used to test the hypothesis that people who have been directly involved in the design and construction of a project will feel a greater sense of ownership of and long term commitment to the perpetuation/ upkeep of that project. The participatory design methodology used with the groups, drew upon research into the participatory practices of a number of architects including Lucien Kroll, Christopher Alexander, Douglas Cardinal, Samuel Mockebee and Peter Hübner. The practices of these architects were considered in light of Shelly Arnstein's "Ladder of Citizen Participation," which ranks participatory methods on a scale from nonparticipation to citizen power. The same ranking system was also used to formulate a numerical scale to evaluate the author's own exertion of control/influence during the two case studies.
\end{abstract}

\title{
ACKNOWLEDGEMENTS
}

The Jardins Communautaire D'Orleans Community Garden, The Greely Community Association, Lucie Fontein, Douglas Cardinal, Morgan Ip, P. Kariouk, J. Debanne, K. Crossman, I. Singh, M. Baez, S. Todd, Dr. P. Stockdale, The Civic Hospital Neighborhood Association Reid Park Project, The Glebe Community Association, The Just Foods Network, Andrea Yeatman, Linda and Larry Bushey, Beth and Meagan Conway, Dr. B. Latimer, Danny Penicud, Emma Jackson, Nick Groves, Shannon Martin and Mike Hilchie. 


\section{TABLE OF CONTENTS}

\section{PART ONE}

1.0 Introduction p.1

1.1 Precedents p.4

1.1.1 Douglas Cardinal 0.4

1.1.2 Morgan Ip p?

1.1 .3 Lucien Kroll 0

1.1.4 Peter Hübner

1.1.5 Christopher Alexander

1.1.6 Samuel Mockbee p.18

1.1.7 Will Alsop

\subsection{Conclusion p.25}

\section{PART TWO}

2.0 The Experiment p.26

2.1 Intro, Methodology \& Strategy p.26

2.2 Self evaluation p.26

2.3 Contact \& Selection p.29

2.4 Case study 1: Orleans Community Garden p.31

2.4.1. Intro ip. 3

2.4.2 PRE workshop summary piz

2.4.3 Workshop\#1: Analysis \& Precedents 13.4

2.4.4 Workshop\#2: Design Charette p.?

2.4.5. POST workshop summary p.48

2.5 Case Study 2: Greely Community Association p.52

2.5.1. Intro

2.5.2 PRE workshop summary p.5:

2.5.3 Workshop\# 1: Analysis \& Precedents 0.54

2.5.4 Workshop\#2: Design Charette p.s?

2.5.5. POST workshop summary p.:8

2.6 Case Study Comparison and Conclusions p.69

2.7 Conclusion 0.73

$\begin{array}{lll}2.8 & \text { Bibliography } & 0.77\end{array}$

2.9 Appendices $\quad$ p.77 


\section{LIST OF FIGURES}

Figure 1: "Ladder of Citizen Participation"

Arnstein, S. R. "A ladder of citizen participation". Journal of the American Institute of Planners, Vol. 35, No. 4, July 1969. p, 216

Figure 2: Douglas Cardinal and the Ouje-Bougoumou Cree

Digital image. Douglas Cardinal Architect Inc. Web. Sept. 2011. <http://djcarchitect.com/02proj_mpouj.htmi>

Figure 3: Cardinals concept sketch of the design process

Digital image. Douglas Cardinal Architect Inc. Web. Sept. 2011. http//djcarchitect.com/01 arch_philosophy. htmls

Figure 4: Morgan Ip and The Cape Dorset Group, courtesy of M. Ip

Figure 5: Participant sketch from design charette, courtesy of M. Ip

Figure 6: Final floor plan and section, courtesy of M.lp

Figure 7: $\quad$ University of Louvain, MéMé Student housing

Milgrom, David. "16: Lucien Kroll:" Space, difference, everyday life: Reading Henri Lefebvre. By Henri Lefebvre. New York: Routledge, 2008, p. 273

Figure 8: French student uprising poster

Arnstein, S. R. "A ladder of citizen participation". Journal of the American Institute of Planners, Vol. 35, No. 4, July 1969. p, 216

Figure 9: Human chain to sod roof at Stuttgart Youth Club

Blundell-Jones, Peter. Peter Hübner: Building as a social process. Stuttgart: Edition Axel Menges, 2003. p.43

Figure 10: Preparation for "Earth-Feast",

Digital image. Plus+ Bauplanung GmbH. Web. Sept. 2011. <http:/www.plus-bauplanung.de/dna/1899_ Wangen.htmls.

Figure 11: Book cover, A Pattern Language

Figure 12: Book cover, The Oregon Experiment

Figure 13: Collaborative home building; Earth rammed tires

Digital image. Fellow Profile Steven Hoffman. Enterprise Rose Architectural Fellowship. Web. Sept. 2011. http:// dev.rosefellowship.org/fellows/stevehoffman/\# >.Photo credit: Timothy Hursley.

Figure 14: Mockbee's Art-Architecture; "Children of Eutaw Pose Before Their Ancient Cabins."

Digital image. The Official Website of Samuel Mockbee. 02009-2012 by the Mockbee Family. Web. Sept. 2011. <http://samuelmockbee.net/work/art/eutaw/>.

Figure 15: The " $5^{\text {th }}$ Wall" of the Sharp Center. Toronto

Porter, Tom and Alsop, Will. Will Alsop: The noise. London: Routledge, 2010.p.21 
Figure 16: $\quad$ Alsop studio

Sketch Book, 2004. Digital image. All Design-Paintings. Alsop Lawrie Limited. Web. Sept. 2011 . <http://www. all-worldwide.com/how/paintings/>.

Figure 17: Response Control Assessment

Figure 18: Traditional vs. Participatory methodologies

Figure 19: Spreading Mulch

Digital image. Orleans Community Garden. 02007-2008 Jcocg.org. Web. Sept. $2011<$ <ttp:/www.freewebs. com/jardincommunautaireorleanscommunitygardens/apps/photos/photo?photoid=6368703>.

Figure 20: Group design guidelines \& objectives

Figure 21: Scale figures

Figure 22: The two selected sketch models

Figure 23: Response Control Assessment, Orleans

Figure 24: "Bloom" option

Figure 25: "Flight" option

Figure 26: Brandon's Sketch

Figure 27: Expo 67 Postcard

Digital image. Expo67 in Montreal Website. John Whelan. Web. Sept. 2011. <http://exp067.ncf.ca/rare_view_ canada_pavilion_expo67.html>. Photo credit: O by Benjamin News Company, 1967.

Figure 28: Response Control Assessment, Greely

Please note unless otherwise stated images/illustrations are property of author. 


\section{APPENDICES}
A. Email sent to groups
B. Group hand out
C. Community Association meeting summaries
a. Fairlea Community Association
b. Civic Hospital Neighbourhood Association, Reid Park Project
c. Glebe Community Association Tot Lot Project
D. Greely presentation material for the City of Ottawa
E. Your Ottawa Region Article
F. Orleans Community Garden Handbook 1st draft
G. Orleans Community Garden Build Day 1 photos 


\subsection{Introduction}

This thesis investigates the role of the architect as a facilitator with the end user in the design-build process. My working hypothesis is that people who have been directly involved in the design and construction of a project will feel a greater sense of ownership and long term commitment to the perpetuation and upkeep of that project. This hypothesis is tested through two practical case studies involving the design and construction of two small structures with local community associations.

The degree of the architects influence and the amount of participation from the group, will be analysed using the framework of Sherry Arnstein's"Ladder of Citizen Participation."

Arnstein's ladder was born out of a need to give definition to the widely used term "citizen participation." Written in the late 1960's during the civil rights movement, terms such as "community consultation", "grass root process", " participatory planning", "community collaboration," "self help", "maximum feasible involvement of the poor", "absolute control","citizen involvement", and "citizen power" were used widely regarding the pressing issues of social inequality.

As the Director of Community Development Studies for The Commons, a non-profit research institute in Washington, D.C. and Chicago, and former Chief Advisor on Citizen Participation in the United States Housing and Urban Development program's Model 
Cities Administration, Arnstein sought to answer the question:

\section{What is Citizen Participation?}

Using three federal social programs - urban renewal, anti-poverty and Model CitiesArnstein set out to create a "typology which is designed to be provocative" and "encourage a more enlightened dialogue"2 of citizen participation. The typology that she used is a ladder with eight rungs, each "corresponding to the extent of the citizen's power in determining the plan and program."

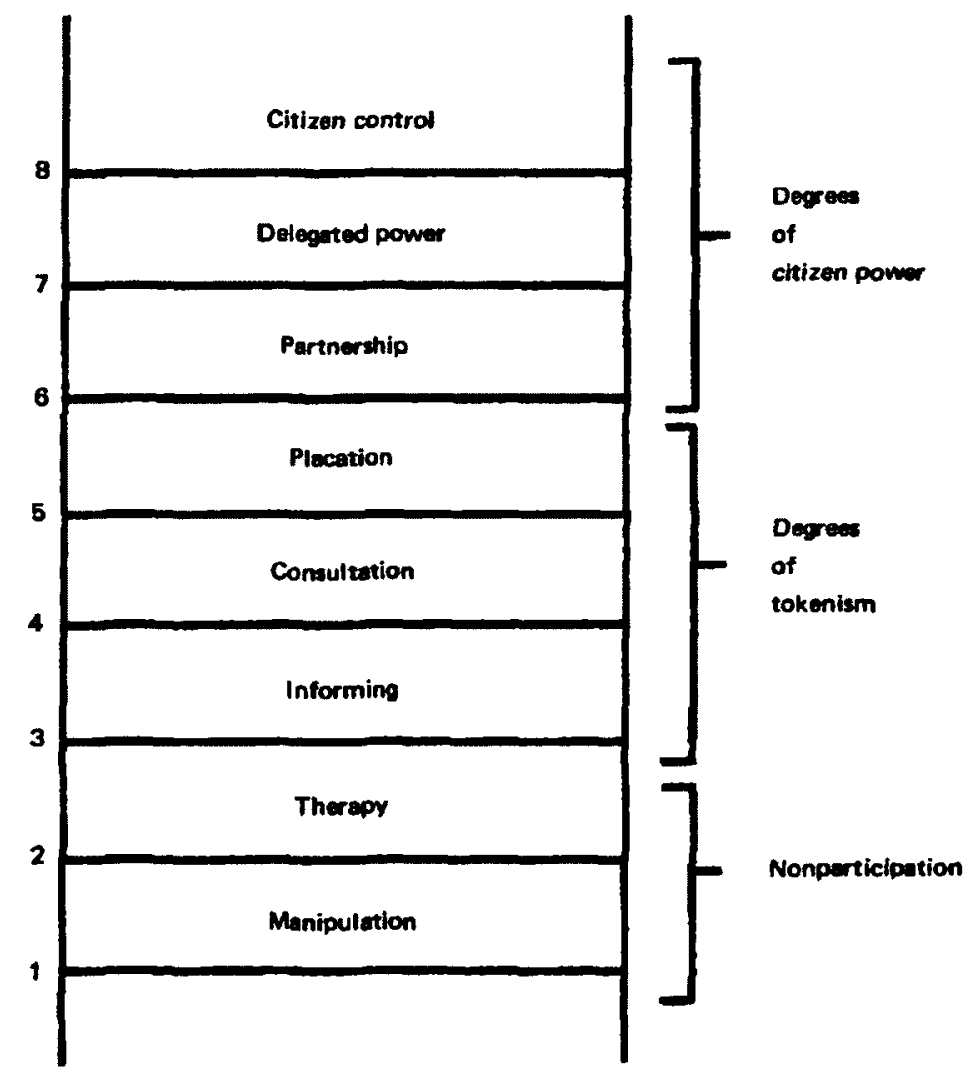

Figure 1: Arnstein's Ladder of Participation

1 Arnstein, S. R. "A ladder of citizen participation". Journal of the American Institute of Planners, Vol. 35, No. 4, July 1969. p. 216

2 Ibid. 216

$3 \quad$ lbid. 216 
Arnstein's answer to the definition in question is:

"....citizen participation is a categorical term for citizen power. It is the redistribution of power that enables the have-not citizens, presently excluded from the political and economic processes, to be deliberately included in the future. It is the strategy by which the have-nots join in determining how information is shared, goals and policies are set, tax resources are allocated, programs are operated, and benefits like contracts and patronage are parceled out. In short, it is the means by which they can induce significant social reform which enables them to share in the benefits of the affluent society." ${ }^{4}$

Using Arnstein's ladder as a barometer, I will be analyzing the level of citizen involvement in the architectural methodologies of Lucien Kroll, Christopher Alexander, Douglas Cardinal, Samuel Mockebee, Peter Hübner and the thesis of Morgan Ip.

In order to test/monitor my own influence on the two participatory projects that I undertook in this thesis, I also created a numerical scale based on Arnstein's typology and 'graded' myself when reviewing the recorded audio from the design sessions. My strategy was to take on the role of facilitator and remain as neutral as possible in order to increase/ensure the genuine empowerment of the members of each group as a result of their participation.

The practical case studies were selected as follows: I emailed 18 local community groups, offering my services as a facilitator in a collaborative design-build project of their choice (see Appendix A for a copy of the email). I was looking for groups that met the following $4 \quad$ Ibid. 216 Author added italics for emphasis 
criteria: were non-profit, would provide 3-7 participants, would be willing to meet for a minimum of 2 design and 2 build workshops, and would be able to substantially complete the project by a March 2012 deadline. In the end, I decided to work with two groups: The Orleans Community Garden and the Greely Community Association.

\subsection{Precedents}

The following architects have been either directly or indirectly influential in the development of the participatory process that I have explored in this thesis.

\subsubsection{Douglas CARDINAL}

1934 Alberta, Canada / Organic Architect
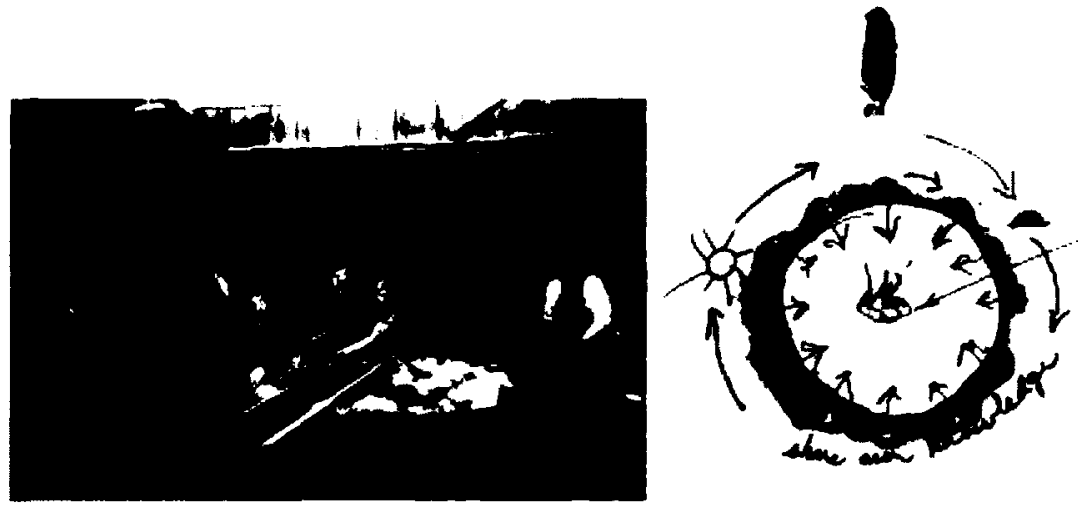

Figure 2: Douglas Cardinal and the Oule-Bougu-mou Cree

Figure 3 Cardinal soncept sketch of the design process

Douglas Cardinal's architectural philosophy can be summarized by contrasting 'Two World Views.' The 'White Mans' world view is one of hierarchy fuelled by power and control. The 'Indigenous' world view is one of interconnectedness and circular process, always returning back to the source for direction. This philosophy is the backbone for an architectural process that commands a high degree of dedication and involvement from all parties. Cardinal believes that everyone has something to contribute to the vision, and that all the answers for a community project lie within the community itself. 
Each new project begins with a 'Vision Session:' This is considered the pre-design phase, an added phase to the usual 5 stage architectural process. All persons affected by the project are invited to attend. Newspapers, radio announcements, posters and emails are sent out to announce the date and time of the Vision Session, which can last anywhere from a day to a week, depending on the number of participants. The session is held in a central location and begins with Cardinal introducing himself, his beliefs and related works. Next, a microphone is passed around and all are encouraged to share their dreams, fears, concerns, needs, wants and expectations for the project. During this part of the process, Cardinal usually doesn't interject or ask questions. There is also a less formal component to the vision session wherein ideas are shared at a communal dinner or celebration and members of Cardinal's family sometimes join him.

After Cardinal has processed the received information, he returns to the group and presents his interpretations of what their vision. The group asks questions, clarifies, corrects, and provides feedback. Cardinal will draw diagrams to communicate concepts with the group, but does not at this point draw architectural sketches or renderings at all. The unique pre-design process is concentrated not on creating an actual design per se, but rather gathering the vision of the community, including an inventory of resources. ${ }^{5}$

The deep involvement that Cardinal asks of the participants, he also asks of himself. Cardinal is passionate about his work, which he sees more as a mission than a regular job. He advocates on behalf of groups, gives speeches, presentations, write ups, joins protests, makes appearances, and donates his time and money to support the dreams that have been entrusted to him by his clients. Based on my 6 years of experience in his office, Cardinal never worked a 9-5 day. He was 'on' all the time, trying to bring

5 Above information based on personal experience in the office of Douglas Cardinal between 2004 and 2010 
meaningful architecture into reality.

I am grateful that my first real experience in the world of architecture was in Cardinal's office. Being exposed to a non-traditional practice, led by an architect who is known for breaking the rules and pushing the boundaries, led me to question my own preconceived notions of the role and responsibility of an architect in society. Cardinal focuses on a high degree of interaction with the end user, and a methodology to uncover the unique spirit and desires of each group that he works with, yet his signature style and iconic flair shines brightly. This dichotomy of the influence of the individual in a participatory pursuit laid the framework for this thesis. 


\subsubsection{Morgan IP}

1978 Ontario, Canada / M.Arch., Carleton University
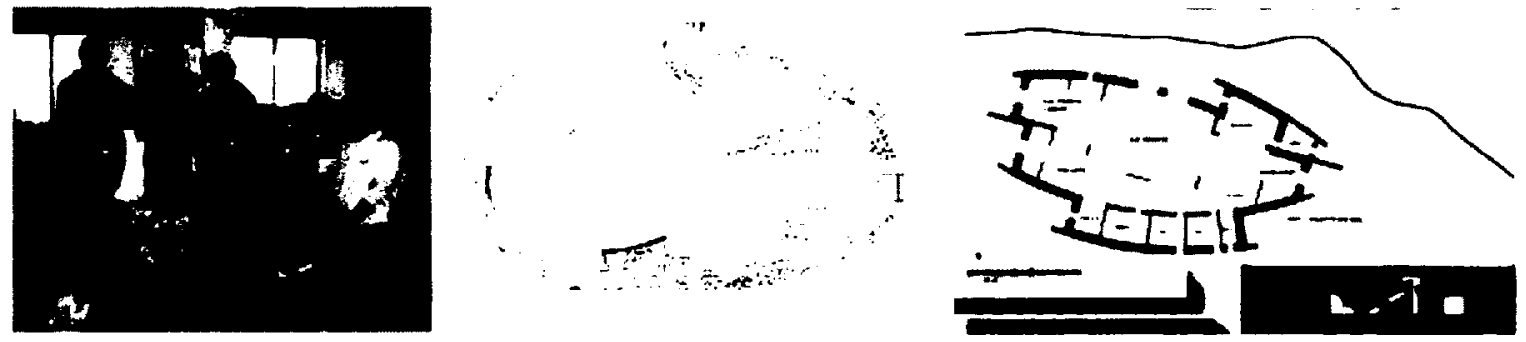

Figure 4: Morgan Ip and The Cape Dorset Group

Figure 5: Participant sketch from desigr crarette

Figure 6: Final floor plan and section.

For his 2009 Thesis entitled: Architecture and Healing: Culturally Appropriate Design in Canadian Arctic, Ip collaborated with the Cape Dorset First Nation's to develop a design for a community centre. The design was to be used as a fundraising tool, and to act as a catalyst to encourage local participation in the built environment.

Ip's process was similar to Cardinal's in that the early sessions consisted mostly of the group talking and Ip listening, taking notes and asking open ended questions. Information was gathered in formal meetings and in social situations over a number of trips to Cape Dorset during the school year. Ip also increased the participation of the group by inviting them to take part in design activities.

According to Ip, pens and paper were spread out on tables and participants were encouraged to draw out their ideas for the center as best they could. Despite the preliminary nature of the drawings, Ip remarked that a common idea began to appear: a central multifunctional space with smaller rooms around the circumference. There was a notable absence of corridors with all programmed spaces being directly linked back to a circular space. Desired spatial relationships between the programmed elements also became clear. For example, the elder room and play room were adjacent and the butchering room had to be on the south side of the building, down wind from the main 
entry. Certain literal images such as eagles and tomahawks were drawn in great detail. An interesting feature of the community centre design generated by the group was a snow wall that acted as an entry vestibule and corresponded to the changing seasons. ${ }^{6}$

Ip's thesis provided many lessons that I used to generate my own methodology for working with community groups. He expressed the importance of clarity regarding the extent of your involvement in the various phases of the project and taking care not to make promises that you can't keep. In his experience, being flexible was key to increase participation. He underlined the fact that people are unaccustomed to being asked to contribute at all, and so asking them to join in design activities is usually well outside their comfort zones. He recommended having a plan but being flexible enough to follow the interests of the group should they lead in a different direction.

Ip also addressed some of my fears about being seen as an 'outsider,' that I wouldn't be accepted by the groups because I didn't have a vested interest in the betterment of the community, but only in the project itself. Ip suggested two things that could help: one was to meet the groups on their turf, and the second, a First Nation's tradition, was to bring a small gift ("an offering") when meeting for the first time.

When asked if there was anything that Ip wished he had done differently or would like to do over, he said he wished that he had been more diligent about maintaining a continuing relationship with the group. This conversation reinforced the idea that my thesis had to address more than just the design component of the project. There had to be intent to build in order for me to be able to effectively evaluate the success of the project on the Arnstein "Ladder of Citizen Participation."

6 September $252011,3 \mathrm{pm}$, Ottawa, Interview with Morgan Ip. 


\subsubsection{Lucien KROLL}

1927 Belgium / Atelier d'Urbanisme, d'Architecture et d'Informatique

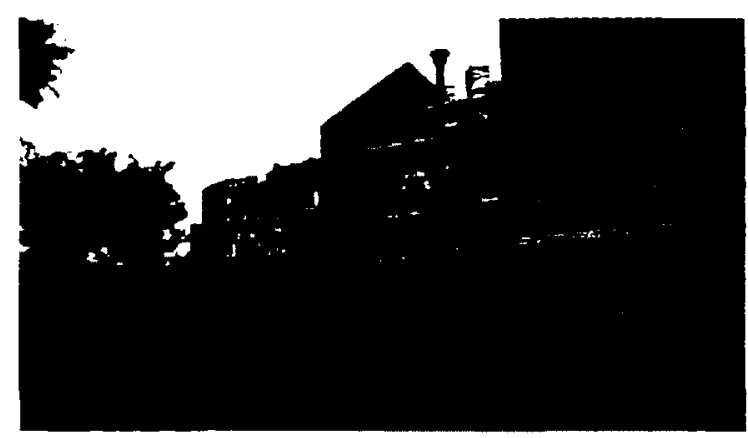

Figure 7: University of Louvain. MeMe Student housing

Figure 8 . The poster is one of about 350 produced

in Mav or June 1968 at Atelier Populaire. a graprics

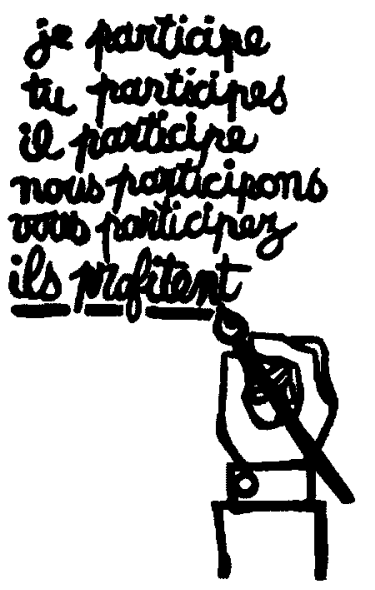

I participate you participate he participates we participate you participate... They profit.

A pioneer of participation, Kroll was chosen by the students of University of Louvain in Belgium as the architect for their new dormitory. This shift in power-from the administration to the students- was "characteristic of the political climate of the late 1960 's", culminating in the great student uprisings in $1968 .{ }^{8}$ The MéMé student housing project of 1970 was one of the first formal examples of participatory architecture in Europe, and remains the one for which Kroll is best known. As in every project, Kroll insisted on student and staff involvement before taking the commission.

On Arnstein's ladder of citizen participation, the MéMé project and Kroll's methodology would rate within the top two rungs of "Citizen Power." The 'citizens,' in this case the students, intervened in the typical university design and build process. The students demanded to be involved and took charge of selecting the architect, in contrast to the typical 'top down' selection process. The students had direct influence on the design of the building, from model building to space planning and even physical construction.

$7 \quad$ Arnstein 216

8 Hill, Jonathan. "The Use of Architects." Urban Studies 38.2 (2001) p. 351 
Also, the interior of the building is based on moveable partitions so that future residents can have a degree of control over their space. Decision making power was also transferred to the builders, allowing them to make some design decisions.

"The pattern of the window openings, the changes of wall materials and the brick sculptures were often left to the discretion of the workers. This involvement of the workers as users makes Kroll's spatial practice still more inclusive and adds yet another layer of complexity to the built environment." 9

One of the common criticisms or concerns of participatory architecture is that nonprofessionals and user-led design will create a chaotic and unstable atmosphere. Kroll points out however, that planning and architecture for the last two or three thousand years have been undertaken by lay people, and indeed have produced some of the most loved, most visited and photographed places in the world. He also points out that variety, change and customization are going to happen in any case. People innately want to alter their environments to make them their own. He believes that encouraging this process makes people feel

\section{“...instant history, to be rooted in a place."}

I too am attracted to the vernacular - the ancient cities and towns that reveal their history and the passage of time; as continuous palimpsest. However, I do not feel the same way when I look at Kroll's work. My impression is that he is trying to replicate what can only develop authentically over many years. It is possible that he accelerates the process with the encouragement of the participants to alter the environment right from the start.

$9 \quad$ Milgrom 277

10 Ellin, Nan. "Participatory Architecture on the Parisian Periphery." (Journal of Architectural Education 53 2000).p.179. 
Either way, I question the value of deliberately creating an aesthetic that is piecemeal and incoherent; a false representation of layers that are built up over time. To me his work looks out of place, when ironically it is supposed to provide 'instant roots' for the inhabitant.

However, according to Kroll, it really doesn't matter what I think. The only people whose opinions matter are the current and future inhabitants of the building"1. I understand that the inhabitant's input should come first, especially regarding the interiors. However, I also feel that the population at large must be considered when building in a public place as part of a streetscape or campus.

11 Milgrom 273 


\subsubsection{Peter Hübner}

1939 Germany / bauplanung GmbH

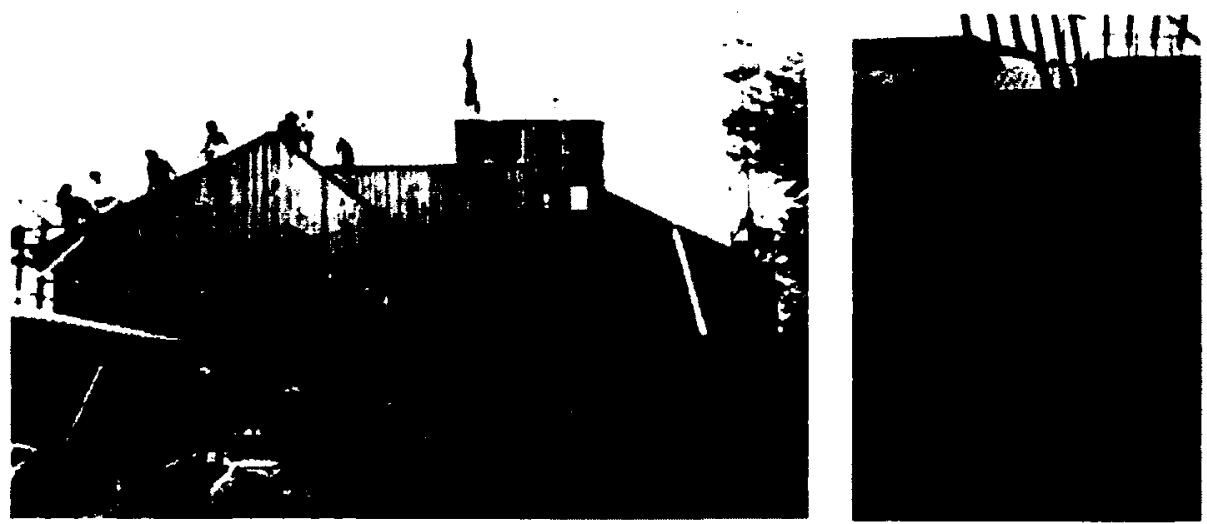

Figure 8: Human chain to sod the roof at Stuttgart Youth Club

Figure 9: Preparation for" Earth-Feast"

Peter Hübner's career has mainly focused on participatory projects in the educational realm: dormitories, kindergartens, youth clubs and recreation centers. His advocacy of participatory architecture is closely intertwined with his advocacy of humanistic pedagogies such as the Steiner philosophy on which Waldorf Schools are based. Both the process and the pedagogy focus on developing the student's collaboration skills, empowerment, imagination, and sense of responsibility for their environment and society in which they live.

There are various levels of collaboration and participation, not only within the architectural realm but in landscape and interior design, too. Sometimes these two other disciplines are treated separately by other firms. Hübner's team is multifaceted and integrated. The landscape isn't separated from the process, or considered as an afterthought. I think that this widened scope also allows for a greater variety of opportunities for people to participate. For example, children tiled the bathroom for the Stuttgart Youth Club; an intricate mosaic of a sun and moon took several weeks to 
complete, and while more decorative than architectural, it allowed for all ages to be involved and for participants to contribute on a level that they were comfortable with.

The Evangelische Gesamtschule in Gelsenkirchen, Germany put out a request for interest to design and build their new school and attached eco-housing. They were intrigued by Hübners proposal; it looked very different from the other firms' submissions of preconceived sketches, renderings and company profiles. Hübner's firm submitted a short story. It was written as an acceptance speech that a student of the Gesamtschule was giving in 2034. In this futuristic tale, the school had won an award in recognition of its environmental leadership and multiculturalism. The project started in 1993, and was generated organically over the next 11 years.

The school actually built the curriculum around the design and construction of the new school. For example, in math class, the students learned about ratios and multiplication by making 1:10 models of themselves; they paired up and traced each other's outlines on large pieces of paper, then helped each other take body measurements and record them on the outline. Then they used these dimensions to build a mini version of themselves out of clay. A triangular scale can be a mystifying to any non architect, but I think that this process allowed the children involved in this activity to develop a much deeper understanding of the modeling process and how it translates into reality. The integration of the self styled 'dolls' also brought a playful and more personal relationship into the building of their new school. ${ }^{12}$

Hübner's work inspired me to think of architecture as community building, that the process is as important as the product, if not more so. His methodology of participation

12 Blundell-Jones, Peter. Peter Hübner: Building as a social process. Stuttgart: Edition Axel Menges, 2003. p.92 
appeals to me also, quite simply because it looks like a lot of fun. From the initial concept stages to post occupancy celebrations, the activities that he organizes with his 'clients' are anything but rote, bureaucratic decision making processes. When it came time to sod the roof for the Stuttgart Youth Club, a large party was held called "Earth-Feast" wherein a human chain was formed to pass bucket after bucket of dirt up to the roof top, followed afterwards by a BBQ and dancing under the stars. ${ }^{13}$

Arnstein developed the Ladder model in order to help locate activities or actions within the wide definition of citizen participation. However, it is the motives behind the scenes that can truly indicate whether the activity is "going through the empty ritual of participation or having the real power needed to affect the outcome of the process." 14 For example, Earth-Feast could have been located on the 'tokenism' rungs of the ladder if the participants had been invited by the 'power holders' as a vehicle for public relations or if this was the only way that the participants had been involved was for the finishing touches. However, because the Stuttgart Youth Club was the organizer and proponent of many activities such as Earth-Feast, there was no hidden motive and the activity remained within the higher rungs of the ladder wherein the participants are the ones with the decision making power.

13 Ibid. 43

14 Arnstein 226 


\subsubsection{Christopher ALEXANDER}

1936 Austria / University of Berkeley California / Center for Environmental Structure
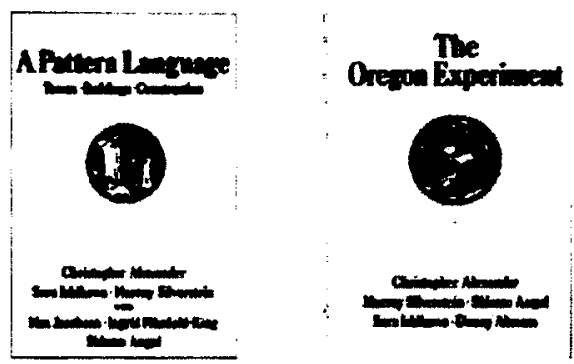

Figure 11: Book cover A Pattern Language

Figure 12: Book cover. The Oregon Experiment

Although he has been teaching at the University of Berkeley, California since the 1960's, has built over 200 buildings and was the first to be awarded a PhD in Architecture from Harvard, Christopher Alexander often slips under the radar of contemporary accounts of history, theory and media. His focus on taking the power and responsibility for the creation of architecture out of the hands of the Architect and placing it into the hands of the end user, has kept him on the periphery of architectural discourse and media.

All of Alexander's writings and publications are written for regular people. No dictionary or special training is required. This doesn't mean that his writings are dry or one dimensional; his methodologies and philosophies value and point towards the importance of feelings, harmony, vulnerability and emotion; qualities that he sees as lacking in most architecture today.

Alexander's book "The Oregon Experiment" is a step by step guide to applying his methods, using the creation of the master plan of the University of Oregon campus as an example. This book clearly outlines his methodology in ordinary language for ordinary people. More importantly for me it answered some of the questions that I had about the participatory process. For example, I had always felt that when people were 
involved in the creation of something, they appreciated it more and took better care of it. However, I wondered what happened when the people who originally worked on the project left? Did it still have value and would it carry meaning on to the next generation? After the participants were gone, should the project be replaced with a creation of the next generation?

Alexander looks at the issue from a different angle. He asserts that the inevitable turnover from one generation to the next is an unavoidable fact of all architecture, and of life in general. He asks us to consider the alternative, where the design is created by those who have no intention of ever inhabiting the space. Alexander uses the example of a PhD student lounge in the physics department. Yes, the original students will be gone after five years, but it makes sense that the next round of physics PhD students will be as comfortable as the first and so on. ${ }^{15}$

The other question that Alexander addresses has to do with the repetitive nature of the process. Will it not produce the same places over and over again? If everyone is following the same guide book, namely "A Pattern Language", isn't that a contradiction in terms? Is it not doing exactly what he criticizes modern architects for doing? Creating works that lack a sense of place and identity?

Alexander explains that a "Pattern Language" does enable people to make unique places because it only provides the patterns to consider- not which ones to use or in what combination. A pattern can be likened to vocabulary in that you can use many different words to describe the same thing, and different sequences or combinations have different emphases and meanings. In a conversation between two people, words are used to communicate, but the same conversation never happens twice. There can 15 Alexander, Christopher. The Oregon Experiment. (New York: Oxford UP, 1975). p.47 
be no effective communication if the two people aren't speaking the same language. Therefore a 'pattern language' provides the 'words' and the users define what kind of sentences they want to create. This ensures that there will be diverse and distinct places that have a strong sense of character and identity, without chaos or conflict. He explains that for the University of Oregon "...the patterns play a role, within the university that tradition played within traditional culture. ${ }^{\mu 16}$

Although there is a clear educational or teaching element to Alexander's process, the aim is not to 'cure' the participants or provide'therapy.' His educational intent is not to get the participants to 'come over to the other side' which as Arnstein says would be "both dishonest and arrogant." 17 Rather, the Oregon Experiment book is basically a 'how-to' manual, it is coming from a place of sharing experience that has been developed by the people, for the people.

Anotherkeycomponent that Arnstein believes is necessary to achieve a truly participatory process is transparency, that "citizens have clear and direct access to the decision making process."18 Through the Oregon experiment, financial statements were readily available to the participants and even published in the public document. Financial transparency and power are included in the highest rung on Arnstein's ladder because it is most often the final step toward citizen empowerment; true decision making power requires the financial backing to carry out the action.

\begin{tabular}{ll}
\hline 16 & Ibid. 37 \\
17 & Arnstein 218 \\
18 & Ibid. 220
\end{tabular}




\subsubsection{Samuel “Sambo" MOCKBEE}

1944-01 Alabama, US / Auburn University, Rural Studio
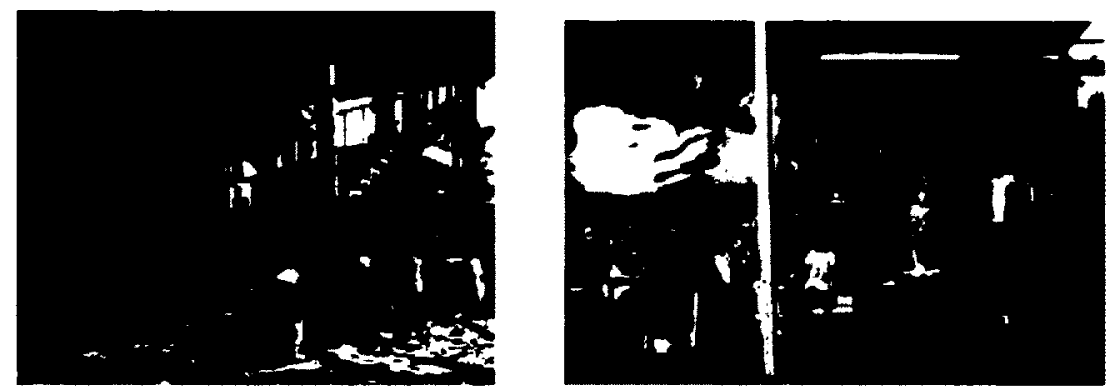

Figure 12: Collaborative home building; Earth rammed tires

Figure 13: Mockbee's Art-Architecture; Children of Eutaw Pose Before Their Ancient Cabins

Mockbee is most remembered not because of his architecture per se, but because of the philosophy that fueled his life's work and that was embodied in a design-build studio he developed at Auburn University known as "Rural Studio."

A native to rural Mississippi, Mockbee returned after a 2 year term in the US Army to finish his architectural studies at Auburn University. Then, after more than a decade of successful practice with a fellow classmate, he returned to Auburn to develop "Rural Studio," a program that has served as a prototype for architectural education all over North America. The program has built over 80 homes and civic buildings in the poverty stricken rural area of Hale County, Alabama.

His methodology is a critique of the architectural profession itself. "Architecture has to be greater than just architecture. It has to address social values, as well as technical and aesthetic values."19 Mockbee challenged professionals to choose "virtue over fortune."20 He felt that architecture was most powerful when it was born of the source; Top down solutions or working from outside the community was too removed and often

19 All Samuel Mockbee quotes: http://samuelmockbee.net/quotes, Web, April 2012.

20 Ibid. 
contributed more to the problem than to the solution.

"The practice of architecture not only requires participation in the profession but it also requires civic engagement."21

Mockbee's work speaks to the Importance of an equal and reciprocal relationship between participants for architecture to be at its best. It is a reminder that an architect must be open to explore different strategies to connect with different groups. Brian Bell, who has taught twelve Rural Studio projects, created an extension to the project for recent graduate students: "Design Corps." In his book "Good Deeds, Good Design" he recounts an example where one outreach strategy had to be tweaked several times before a successful connection was made. The goal was to design healthier and more humane housing for migrant farm workers.

"Over time we learned how to gather this information more sensitively. We first tried to take these surveys at the workers homes. This proved to be an unfortunate mistake on our part, as workers often could not communicate openly out of fear of losing their jobs by criticizing their employers' housing. At the same time they had little opportunity to avoid us and were confused about why we were asking so many questions, despite our efforts to explain. Furthermore, we were possibly interfering with their few minutes of free time or preventing the rest they needed. "222

The students considered trying to meet workers by approaching them while they were waiting for appointments at the Migrant Health Clinic but dropped this idea for fear that 21 lbid.

22 Bell, Bryan. Good deeds, good desian: Community service through architecture. New York: Princeton Architectural Press, 2004. p. 30 
the workers might feel that they were being cornered. Instead the students set up a table at the Sunday morning flea market that the workers could approach on their own terms. A raffle for a stereo was offered in exchange for filling out a survey, however it was quickly realized that many workers didn't have a phone or proper mailing address to be notified if they won.

Finally, the strategy that did work, was offering a cold bottle of water in exchange for filling out anonymous surveys. The workers felt less at risk in terms of their jobs and 'getting in trouble' since the cards were anonymous and participation was totally up to them. It important to note that the survey cards were just a starting point to open a dialogue and for the workers and the students to connect.

Aesthetically, the Rural Studio projects are a colorful mix of modernist angles with a vernacular southern style, and working within tight budgets encourages the innovative re-use of non-conventional building materials; a church made of tires and timber, a community centre with a façade of recalled Chrysler windshields.

This philosophy is shared through Mockbee's art, writings, films, architecture and pedagogy. Rural Studio is an architectural graduate program that runs the regular school year, but it is not uncommon for the students to continue on into the summer to finish a project. Rural studio spawned a movement of design-build programs that connect students with the sometimes harsh realities outside the university walls. When Rural Studio started in 1993, there were only 10 schools in the United States that had similar programs. Today there are more than 40 . Rural Studio has also branched out to run an out-reach program to guide similar ventures outside the university context. ${ }^{23}$

23 Dean, Andrea Oppenheimer. "AlA Gold Medal Winner: Samuel Mockbee." Architectural Record. The McGraw-Hill Companies, June 2004. Web. Sept. 2011. <http://archrecord. construction.com/features/aiaAwards/04mockbee-2.asp>. 
In her article, "A Ladder of Citizen Participation" Arnstein points out that projects can be stuck in a loop that circles the two bottom sections of the ladder: tokenism and nonparticipation. She notes that empty consultation and one-way information sessions fail to accomplish anything except frustration and futility felt by the participants. "Superficial information, discouraging questions or giving irrelevant answers" 24 can basically wear down the participants into giving up or giving in, not seeing any actual change.

In contrast, Rural Studio students meet with the community, selects, designs, and build the project within the school year. The "legalistic jargon and prestige of officials"25 is purposefully absent from Mockebee's methodology.

Samuel Mockbee died of leukemia complications in 2002 and was posthumously award the AIA Gold medal.

I appreciate and am inspired by the fact that Mockbee worked within 'his own backyard.' Although the other architects included in this section of the thesis have worked with marginalized or disadvantaged groups, I consider Mockbee to be the personification of architecture for the other $98 \%$. He lived within, worked within and was a part of the community; you could say he lived 'on-site.' He believed in action, to "Proceed and Be Bold."26

\footnotetext{
$24 \quad$ Arnstien 219

$25 \quad$ Ibid 219

26 "Proceed and be Bold" is the title of 2005 book about Mockbee and Rural Studio by A. Oppenheimer Dean
} 


\subsubsection{Will ALSOP}

\section{7 / Great Britain / ALL Design}
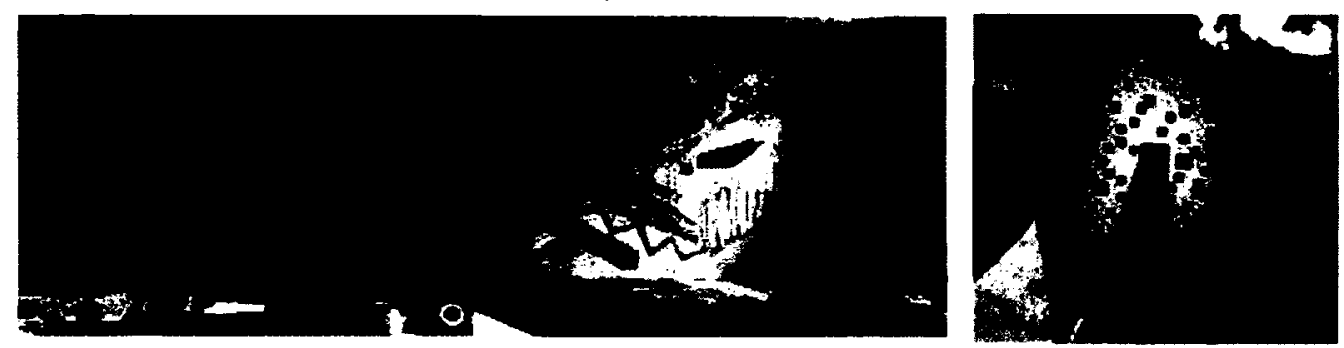

Figure 14: Alsop studio

Figure 15: The " 5 " Wall" of the Sharp Center

Will Alsop's architecture is known for its colorful, bold and playful shapes. His participatory methodology could be described the same way. His buildings are mainly public institutions ranging from city halls to prisons (mostly in the UK), however he has definitely made his mark in Canada. The Sharp Center at Ontario College of Art and Design in Toronto received the 2004 Worldwide Award, from RIBA who described it as:

"...courageous, bold and just a little insane."

Alsop is frequently referred to as an 'avant garde' or 'modernist' architect, however he does not associate himself with any style, movement or 'ism. ${ }^{27}$

Alsop's identity incorporates the artist, the sculptor and the architect all in one, reminiscent of the Renaissance period. He critiques the profession as being more exclusive than inclusive and has traded in his t-square for a paintbrush, enjoying the randomness and spontaneity it provides. He also challenges the hierarchy of the different design disciplines, asserting that architecture is just another branch of art. His London based practice: "ALL Design" follows this assertion in that it practices in many creative disciplines: marketing, furniture, installations, sculpture, paintings and of

27 Porter, Tom, and Will Alsop. Will Alsop: The noise. London: Routledge, 2010. p.35 
course, architecture. ${ }^{28}$

I would suggest that this open-mindedness and inclusivity is an attitude that carries on to his methodology. Participants are not just limited to end-users. For example, for the Sharp Center in Toronto, he sent out 20,000 postcards to the neighborhood, to help pick the color palette and pattern for the " 5 th Wall" - the underside of the floating building. Appropriately, he included in the design process, people who may never set foot inside the building but will live in its shadow everyday. Other participatory architects are more selective about their participants, including only those who will be formally connected with the building. But the building becomes part of the life of anyone who sees it. It becomes part of the greater city fabric.

Alsop's design process includes sessions such as "the Big Draw, the Dream Session, and Design Soup."29 These are 'all hands-on deck' endeavors. However, a key component to his methodology occurs when he picks up his paintbrush and performs solo. This open ended, free form painting process is done within an almost meditative mindset, which he calls, "The Noise." ${ }^{30}$ Alsop revels in the period between concept and form, through unscripted, exploratory painting. Painting is his medium of choice because of its imprecise nature; it's about a feeling - not a prediction of form. He himself doesn't know precisely what it means. This self imposed 'mental limbo' ${ }^{31}$ is just part of his process.

This unique trait or practice of Alsop sets him apart from other participatory practitioners. He has various painting studios, in varying degrees of solitude. For example, The Battersea Studio is a reclaimed store front so that passersby are witness to 
the massive paintings, installations and mockups constantly in renewal. He also retreats to a private garden studio outside his rural homestead.

I think that Alsop's'clients' are keenly aware of his unique process and large body of work before engaging in a partnership with him, and although there is a solo component, the outcome isn't a final design that the group must accept. The solo component is just another method of communicating and processing information that he then presents back to the group to see if he has captured and understood their wants, desires and dreams for the new project.

Arnstein suggests that when the community has the power to hire or fire the required specialists or professionals to make their project happen (such as lawyers, technicians and in the case of Alsop, the architect.) the attainment of the second highest rung in the ladder, Partnership, is reached.

At the end of her article, Arnstein outlines a few common arguments against community control. One of which is the view that "it is incompatible with the merit system and professionalism."32 This too is a common assertion amongst both professionals and everyday people, that architecture is best left to architects. Indeed in the intro to his book "Design Methods" John C. Jones says that it is a common judgment that: "Creativeness is a matter for gifted individuals and that an 'ordinary person' or group cannot do anything new."

I have even questioned myself in regards to this thesis experiment. Am I crazy to want to involve everyday people into the design process? According to Alsop, I am not. "Ordinary

$32 \quad$ Arnstein 224 
people do come up with some great ideas." ${ }^{33}$ In fact, the defining architectural move of the Sharp Centre came from a neighbor who suggested they just lift the building up so that he could still see the park across the way.

\subsection{Conclusion}

Through analyzing the preceding participatory architectural methodologies, I can see that while all rank high on Arnsteins Ladder, I wish to align myself most closely along the architect Peter Hübner.

Hübners methodology puts the fate of the project into the hands of those that wouldn't normally be in control. This clearly aligns him with Arnsteins definition that: "citizen participation equals citizen power." He achieves this high position on the ladder by engaging the participants in actual design and building activities. From sketching, to model making, material testing, fundraising, and actual physical construction, his focus seems to be less about the architectural outcome in the typical sense, and more about the process and people involved. As explained in an anecdote from the book "Building as a Social Process" Hübner revisits the projects that he has worked on frequently, however he asserts that:

"If you want to know about the architecture, talk to the people, don't stare at the building. ${ }^{\prime 34}$

I hope to follow his commitment to the participants and the type of architectural methodology that fosters this kind of relationship. 


\section{PART TWO}

\subsection{Intro, Methodology \& Strategy}

My objective in this thesis was to situate the design process as high up the Ladder of Citizen Participation as possible. Based on my analysis of what are considered to be participatory architects, I was acutely sensitive to the danger of falling into the "tokenism" trap. My response was therefore to approach the role of facilitator of the design process with the intention of remaining as neutral as possible. I found this required considerable concentration and restraint as $\mathrm{I}$ am an opinionated person by nature and have a tendency to be quite vocal in group situations. I was curious to see what would happen. When would I interject? Would l even 'need' to? At what point would my participation be asked for or my 'expertise' be required?

My basic instructions for the workshops were as follows: we would analyse the community to see what kind of architectural project would be most suitable, define our goals and parameters for the design, analyse precedents, create a site model, build sketch models and finally choose a design. I wasn't sure how far the designing could go as a group; how much or how little the group members would want to participate and how much guidance they would want. (see Appendix B for group handout)

\subsection{The Self Evaluation}

In order to gauge the amount of influence that I exerted in the design process, I listened to the audio recordings, read the transcripts and filled out the "Control Response Assessment" (see fig. 16). This was developed as a means to analyze and 'grade' my performance, and a numerical value was assigned to different response options: least control exerted on the design (0) to most control (4). 
Figure 16: Response Control Assessment

\begin{tabular}{|c|c|c|c|c|}
\hline Points & Response & Specifically & \# of & For example: \\
\hline \multirow[t]{2}{*}{0.5} & \multirow[t]{2}{*}{$\begin{array}{l}\text { When asked } \\
\text { adds new } \\
\text { objective info }\end{array}$} & $\begin{array}{l}\text { Scholastic or } \\
\text { knowledge } \\
\text { from previous } \\
\text { architectural projects }\end{array}$ & & $\begin{array}{l}\text { Imparting info regarding footing } \\
\text { specifications, how to make a model etc. }\end{array}$ \\
\hline & & $\begin{array}{l}\text { Material } \\
\text { Sourcing }\end{array}$ & & $\begin{array}{l}\text { Where to get things, ie. inner tubes from } \\
\text { bike co-op }\end{array}$ \\
\hline \multirow{3}{*}{1} & \multirow{3}{*}{$\begin{array}{l}\text { Adds new } \\
\text { objective info }\end{array}$} & $\begin{array}{l}\text { Scholastic or } \\
\text { knowledge } \\
\text { from previous } \\
\text { architectural projects }\end{array}$ & & $\begin{array}{l}\text { Imparting info regarding footing } \\
\text { specifications, how to make a model etc. }\end{array}$ \\
\hline & & Material Sourcing & & Where to get things, ie. \\
\hline & & $\begin{array}{l}\text { Reminds group of } \\
\text { something that they } \\
\text { have already agreed } \\
\text { on. }\end{array}$ & & $\begin{array}{l}\text { "The downside to it you wouldn't have be } \\
\text { using that wood that you liked." }\end{array}$ \\
\hline \multirow{3}{*}{1} & \multirow{3}{*}{$\begin{array}{c}\text { Asks for } \\
\text { clarification } \\
\end{array}$} & $\begin{array}{l}\text { Did you mean? } \\
\text { Do you think? }\end{array}$ & & "You think that red is the best color? \\
\hline & & Is this right? & & "So it's ok to be facing this way? \\
\hline & & $\begin{array}{l}\text { Repeats or } \\
\text { summarizes }\end{array}$ & & \\
\hline \multirow[t]{2}{*}{1} & \multirow[t]{2}{*}{$\begin{array}{l}\text { Asks } \\
\text { questions }\end{array}$} & $\begin{array}{l}\text { To get participation, } \\
\text { because I want them } \\
\text { to consider a design } \\
\text { decision/factor }\end{array}$ & & $\begin{array}{l}\text { "What kind of structure would support a } \\
\text { heavy roof like that?" }\end{array}$ \\
\hline & & $\begin{array}{l}\text { Because I truly don't } \\
\text { know the answer }\end{array}$ & & "What type of soil are you on?" \\
\hline 2 & $\begin{array}{l}\text { Direct } \\
\text { compliment } \\
\text { on design }\end{array}$ & & & $\begin{array}{l}\text { "I like the pattern, the criss-cross pattern on } \\
\text { your model." }\end{array}$ \\
\hline 1.5 & $\begin{array}{l}\text { When asked, } \\
\text { adds new } \\
\text { subjective } \\
\text { info }\end{array}$ & I think, I like & & "I like copper rather than steel." \\
\hline
\end{tabular}




\begin{tabular}{|c|c|c|c|}
\hline \multirow{4}{*}{2} & \multirow{4}{*}{$\begin{array}{l}\text { Adds new } \\
\text { subjective } \\
\text { info }\end{array}$} & I think, I like & "I like copper rather than steel." \\
\hline & & My design opinion & $\begin{array}{l}\text { "... It's the two of them that really give it the } \\
\text { dynamism." }\end{array}$ \\
\hline & & $\begin{array}{l}\text { Suggest design or } \\
\text { design elements }\end{array}$ & $\begin{array}{l}\text { "I could see using some recycled wood } \\
\text { from the palettes and some new wood for } \\
\text { contrast;" }\end{array}$ \\
\hline & & $\begin{array}{l}\text { To initiate a } \\
\text { discussion that I } \\
\text { thought was relevant } \\
\text { or related }\end{array}$ & $\begin{array}{l}\text { Discussing school's influence on our } \\
\text { creative ability or perception of ability. }\end{array}$ \\
\hline 3 & Agrees & & "Yes, that makes sense." \\
\hline \multirow{3}{*}{3} & \multirow{3}{*}{ Disagrees } & Overtly & "I wouldn't choose that location." \\
\hline & & Ignores & $\begin{array}{l}\text { Redirecting the conversation or pretending } \\
\text { not to hear. }\end{array}$ \\
\hline & & Indirectly & Make a joke, sarcasm. \\
\hline 4 & $\begin{array}{l}\text { Refuses } \\
\text { to further } \\
\text { participate }\end{array}$ & & "I quit!" \\
\hline 4 & $\begin{array}{l}\text { Takes full } \\
\text { control }\end{array}$ & & "I am going to do this alone." \\
\hline
\end{tabular}

It is important to clarify that my intention was to analyze my participation in the group design process, not the larger design methodology. Clearly, the role that the architect chooses to take with respect to his/her clients can also be seen as exerting a certain level of control over the design process. I have tried to choose activities that go beyond the traditional architect-client process, thus increasing the level of participation. (see fig. 17) Had I wanted to reduce my involvement even further, I could have asked the group what kind of design activities they would like to do, such as visit precedent projects together, or sharing with the group what they liked or didn't like about a chosen photograph from a magazine. In this case however, since I was 'cold calling' potential groups, I felt that I 
had to offer a basic methodology as a starting point in order to communicate what it was that they would be getting themselves into.
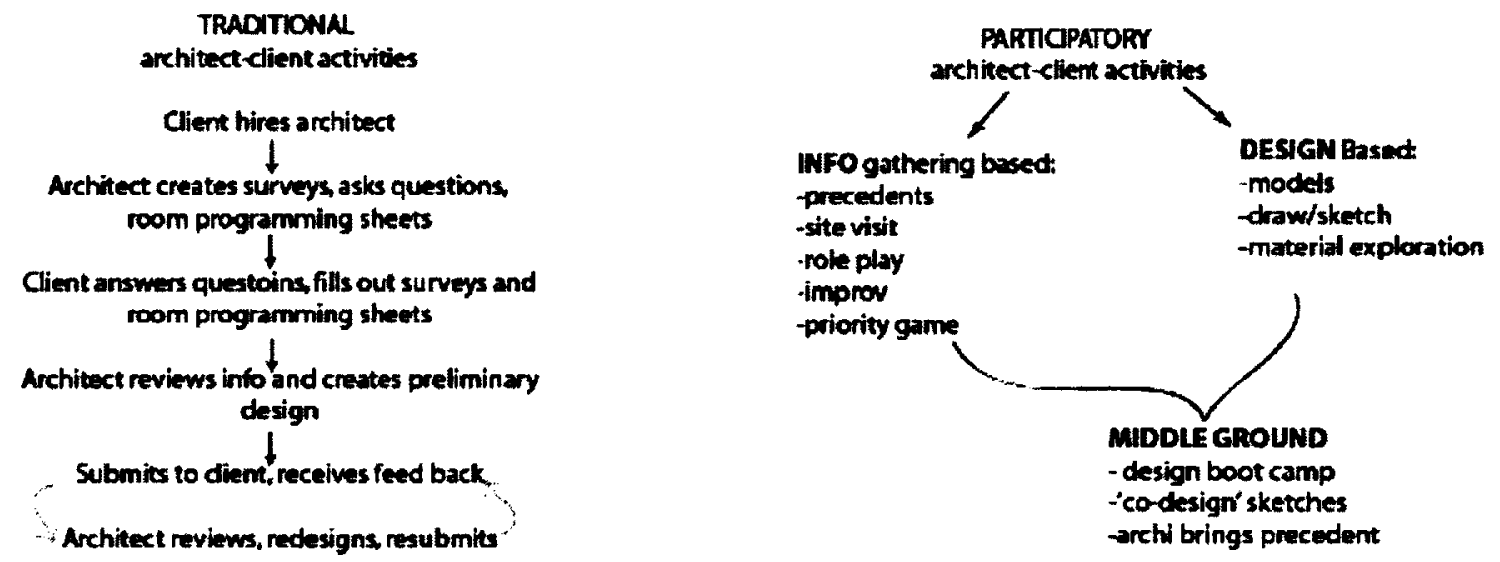

Figure 17: Traditional vs. Participatory methodologies

\subsection{Contact \& Selection}

It was recognized early on when designing this experiment, that while it may be easy to get fellow designer's input and participation in a creative endeavour, it would take more than the promise of a good time to capture the interest and time commitment from a community group. The project had to be something that was important to them, something they would be willing to put their time and energy towards. However, writing an email that asked for participation without predefining what the project could or should be, proved to require a fine balance involving explaining without being prescriptive. My solution was to suggest a possible issue that the group might feel required attention, without pointing to a specific architectural solution. In the email I wrote the following:

"... The garden is flourishing with activity, but there isn't a place to sit back and relax, a place to take time to stop and smell the roses." 35

35 See Appendix A 
What did need to come across clearly in the email was that this was to be a joint endeavour; that I would be working with them, not for them. Also, that this email was simply an invitation to discuss the possibility of working together; that no commitment was needed from either party at this time. Finally, I wanted to be clear that the participants didn't require any previous design-build experience or knowledge; that all that was required was a desire to participate.

I chose to email community groups within the Ottawa area (for the ease of accessibility) and used the online 'Blue Book'36 to find contact information. It was also important that the groups be non-profit and non-political. The two main categories that I concentrated on were community garden groups and community associations. I knew that I had to cast a wide net because at this early point in the experiment, I had yet to find out if there was any interest at all.

Of the 28 community groups that were contacted via email, 11 responded: 3 declined and 8 were interested in finding out more about the opportunity. I met with 4 of the 8 interested parties, and in the end chose 2 groups to work with.

For each group meeting, I brought a handout ${ }^{37}$ that more clearly stated what the process could look like and an agenda for the meeting. There were many points that needed to be addressed that were not included in the original email (in the interest of keeping it short), particularly that the experiment itself was being fast-tracked and was being designed and built in tandem. I explained that I was interviewing 7 other groups and that even if their group were chosen, there were no guarantees that the process would

36 The Blue Book is Ottawa's Directory of Community Services and can be found online at: http:// www.cominfo-ottawa.org/serviceandresourcepublications.html See Appendix B 
end up in a built project. I described the minimal time commitment and number of participants required, the appropriate scale of the project and the intended timeline. Finally, I needed to know if they would be comfortable with me recording our meetings and design sessions. Please see Appendix $\mathrm{C}$ for analysis of all the respondents and meeting summaries.

The two groups that I thought would be the best match for my thesis experiment were The Orleans Community Garden and The Greely Community Association.

\subsection{CASE STUDY 1: The Orleans Community Garden}

\subsubsection{INTRO}

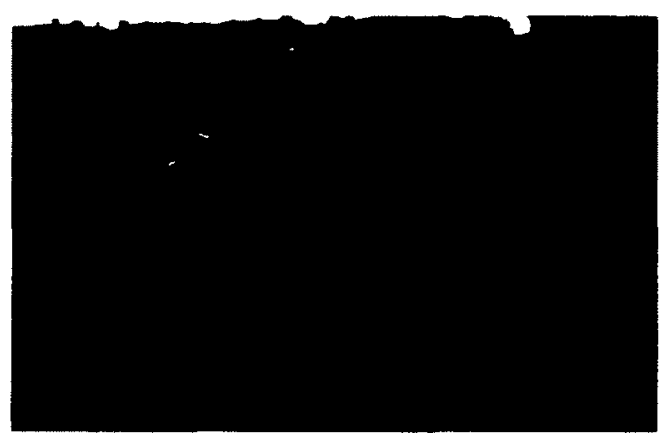

Figure 18: Spreading mulch on new plots
The Orleans Community Garden is one the 30 of gardens in the greater region of Ottawa. The garden started in 2006 and has grown each year to include more than 70 plots, composting bins, a water pump, tool shed, and is in the beginning stages of creating a $1 / 4$ acre fruit orchard on the east end of the site. Orleans is a large suburb 20km east of Ottawa with a population of about a 100,000 residents, which includes a large French speaking community. Creole and Chinese can also be heard on any given day at the garden. Vegetables are grown for personal use but there is also a plot for the food bank; communal chores are done by sub committee members and there is a core committee that includes a chair, vice, treasurer and operations manager. There are no paid positions, 
it is all volunteer run.

\subsubsection{PRE workshop summary}

In September, the first emails that were exchanged with Gina, the chair, really caught my attention because of her eagerness to improve and add to the garden. It sounded as if she had a good group of supporters, including their local MP and surrounding businesses. I was invited to present to the group at a member's house during one of their regular committee meetings. I brought Timbits and copies of the project outline..$^{38}$

The objective of this meeting was to assess whether the group and I would be a good match for project. Considerations included: Would they have enough interested people? Were they willing to follow the methodology and participate in the meetings? Did they have a suitable project in mind? Did they understand and were they interested in 'architectural design' v.s. 'art' or a replication of an existing structure? Did our time frames match? Did they have a way to secure funds or materials? Finally, did they clearly understand that my role would be as a facilitator of the process as opposed to designing the project for them.

I also wanted to learn about how the garden functions and is organized, what its membership is like and the history of how it came to be. What I remember most vividly from this meeting was that it started off with the committee members saying that they weren't creative, and expressing doubts regarding their ability to contribute to a design project such as this. However, shortly thereafter, the conversation was buzzing with ideas as to what they could see the project becoming. I tried unsuccessfully a couple times to bring the conversation back to the fact that we didn't need to solve the problem now 
or design anything at this meeting; the purpose was just to meet and see if we felt that both parties could achieve their goals through this process.

I left the meeting so that the members could 'talk amongst themselves.'I let them know that over the next few weeks I would be meeting with several other groups and that I would be making a decision by October $26^{\text {th }}$. Shortly after the meeting that night, Gina emailed me to let me know that they group was very interested and had allocated $\$ 300$ for the project.

At the end of the month, I was pleased to let the group know that they had been selected and that I would see them on the closing day of the garden to meet the gardeners and get acquainted with the site. I felt confident choosing this group because they had a realistic scale of project in mind, they had an active pool of members, they were eager and excited to be involved and had a good understanding and acceptance of the parameters.

The visit to the garden was on a beautiful fall day. The garden was full of activity as the members were getting the site ready for winter. During this visit I learned more about the workings of the garden, what types of vegetables grew best, what the soil was like and introduced myself to a few gardeners.

At the annual general meeting in early November, I presented the project to the broader membership. About 10 people attended including the local MP, Bob Monette. He offered his support by allowing us to rent a room free of charge at the local library for our design meetings. I suggested that we meet for a minimum of 2 design sessions of 2 hours each. I realised at this meeting that people who attend these meetings are 
already busy people. They volunteer so much of their time already to the garden that an added project was a bit of a hard sell. However, Gina was confident that we would find enough willing bodies to participate in the design meetings, and that support for the actual build would be even greater. I suggested that we send out an email to the rest of the gardeners that didn't attend the meeting. Gina said that we could try, but that she didn't think she'd get any response. She was right. The people that wanted to participate were the chair, the treasurer, the VP and two regular members.

With the holidays fast approaching, we set the meetings for the following two Wednesdays; November 15 and 22.

\subsubsection{Workshop \#1: Analysis and Precedents}

Nov 15 2011, Orleans library, 7-930pm: Lee, Sylv, Gina, Pat and Nan

This was the first of our two workshops. Our goal was to select a final project type to develop in the next session. I arrived early to set up the room and post our agenda on the wall: 1. Precedent Research, 2. Site Analysis, 3. Inventory, 4. Project ideas and 5. Select one project to work on in the next workshop, the design charette.

To gather precedents we headed to the architecture and garden sections of the library. I told the group to choose any books or magazines that they felt were relevant to the project. To add to the Orleans library selection, I brought books from the Carleton Library as well. I chose books on materiality and contemporary small scale structures. I avoided any particular 'style' or single architect. In addition, I brought print-outs from the internet that showed what other community gardens are like, and outdoor public architecture. I also brought three examples of my own work to discuss and present to the 
group. These projects were group design-build projects done in $3^{\text {rd }}$ Year, were relevant in scale and showed how ideas can be translated through inventive use of materials. I felt that the risk of influencing the group with my own 'style' was outweighed by being able to thoroughly explain the thinking behind a project, compared to guessing at the motivations and decisions for projects that we saw in books and magazines. I also wanted to reassure the group that I had real experience in this type of collaborative project. I asked the group to mark any pages (with post-it notes) that they found interesting, appealing or unappealing, whether it be for the way that a material was used, for the layout or for its relevance to our yet to be defined project.

While flipping through the books, it was clear that the group was more interested in, or at least pointed out a lot of non-architectural ideas for the garden: decorative elements such as weather vanes, sculptures and birdhouses. This was a good opportunity to discuss and define what architecture is and isn't. Gina had previously described it to the group as 'working art'. I commended her for such a good description, however, since this could also produce a creatively designed bench or water fountain, we added 'inhabitable' to the definition.

I didn't want to discourage any conversations or ideas, even though most of the talk so far had been about decorative elements, so I suggested that we create a list of all the ideas the group had expressed interest in. On the table I divided a large sheet of paper into 4 quadrants: one for the non architectural ideas, one for the assets and shortcomings of the garden, one for possible materials and one as a list of points that would influence our design, such as the importance of low maintenance and high durability. I think the inclusion of the non-architectural ideas into the discussion was a good idea, because no one was being shut down by not being on task, especially when the group was just 
learning about what constitutes architecture.

Some of the positive points that the group brought up were that the garden was well organized and managed, that it was a natural and clean location, that there weren't any ground hogs, and that members felt safe there. The areas that needed attention were that vegetables sometimes went missing, that there was no shade to rest in and that for some gardeners it was a long way to the well to fetch water. The design considerations that the group came up with were:

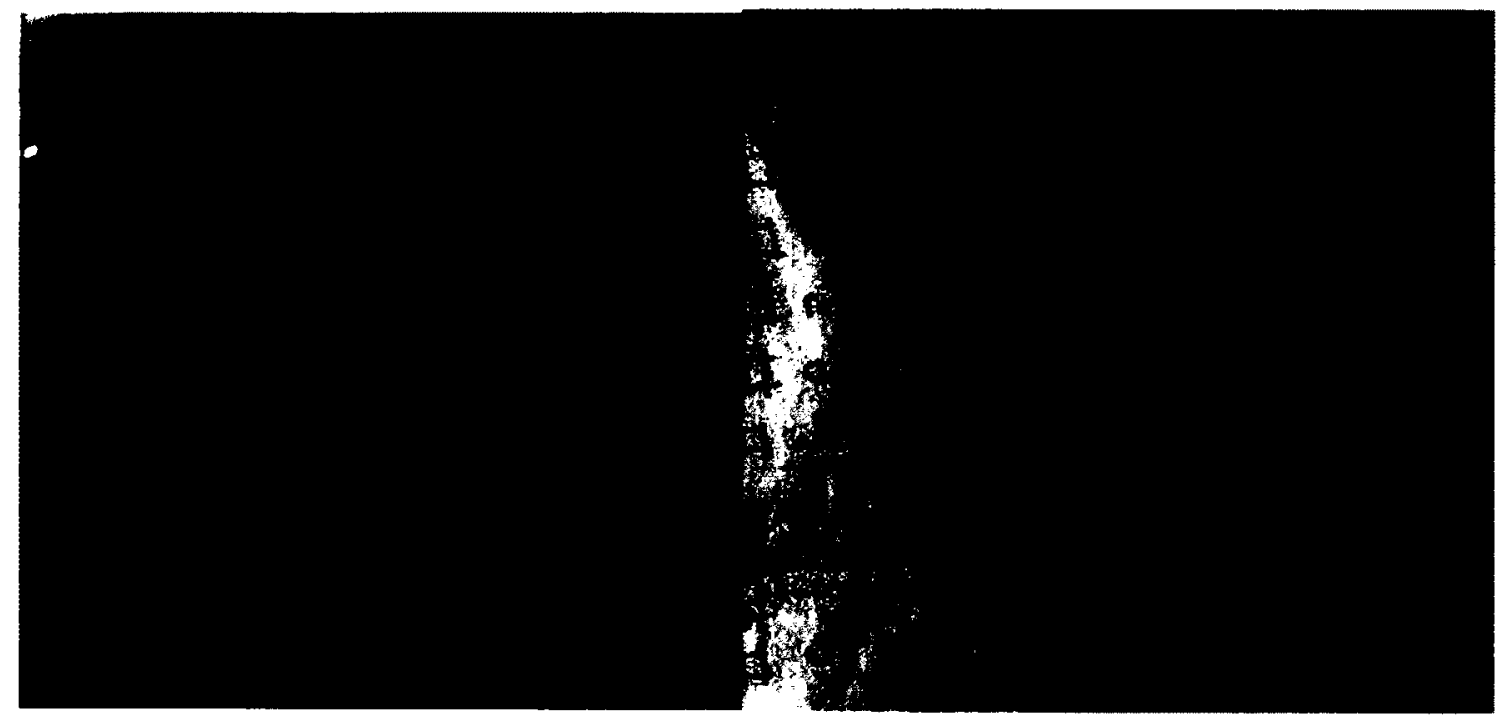

Figure 19: Group design guidelines and objectives

From these points we began to suggest solutions. It became quite clear that the architectural element that the group wanted and needed most was a shade structure. In previous seasons, gardeners would go up on to the adjacent ridge to sit in the shade from the trees, or bring beach umbrellas. While both of these did provide some relief from the summer sun, the group thought that a better solution was possible. I facilitated the conversation by asking the group to imagine and describe a day in the garden with and without the pavilion. Opening day ceremonies, BBQ fundraisers and even the new garden book club would have a special place in the garden. The pavilion's primary 
purpose would be to provide shade, but it would also act as a meeting place, a landmark and testament to the gardeners' imaginations, hard work and community values.

By the end of the meeting, the project and parameters had been very clearly defined and the group was in agreement and excited about next week's workshop: the "Design Charette."

\subsubsection{Workshop \#2: Design Charette}

Nov 282011 , Orleans library, 7-930pm: Lee, Sylv, Gina, John, Pat and Nan

The objectives for this meeting were to complete a site model, do a solar analysis and build sketch models of the ideas that we had discussed in the previous design charette. Out of concern for time, I had constructed a 1:500 site model before the meeting. The model still needed trees so the group added them while we talked about site related issues such as soil types, wind direction and future plans for the garden. We used a hand held lamp to simulate the sun.

I chose to bring a variety of model making supplies; some that likely were foreign to them, such as a scale ruler, but also more familiar items, such as shish-ka-bob skewers and 'smelly markers'. I marked standard wood dowels from the model making store with different colors to indicate different sizes at the scale that we would be using. (i.e. $2 \times 4$, $4 \times 4)$ This idea didn't seem to help the group make design decisions or understand scale, so I wouldn't use this system again. What did prove to be an effective tool in this regard was that I provided everyone with a scale picnic table and human figure. In the future, I would keep the site model and the sketch models at the same scale as it was difficult for the participants to switch back and forth between the two. The human figure models 


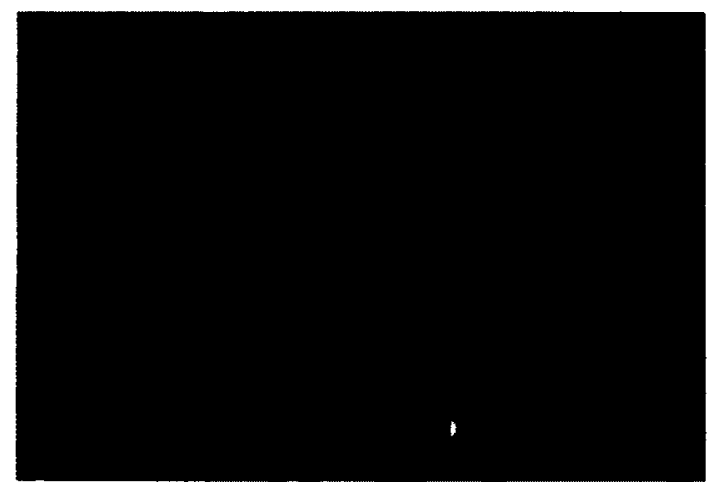

Figure 20: Scale figures

seemed to lighten the mood and reduce the 'seriousness' as the group 'played' with them, gave them names and animated little scenes.

Since our very first introduction, I tried to emphasize that this was a discovery process, meant to be fun, in order to offset any anxiety that group members might have had about doing something new and potentially intimidating. Three of the five participants in this case had previously expressed that they were not 'creative people and that they weren't sure what they would be able to bring to the table. Some were more craft oriented than others. Gina, for example, quilts, bakes and scrapbooks and therefore needed less encouragement to participate; others were quite hesitant to get started. The 'challenge' with creative people is that they tend to take over the group, while the others are silent. For example, Sylvie didn't speak up until $1 \frac{1}{2}$ hours into the meeting. This is where the role of the architect as facilitator could come in, to find ways to interact and draw people into the creative process. In hindsight, I should have engaged Sylvie more, maybe through questions or supportive comments; maybe to talk about things that didn't have direct connection to the architectural task at hand, but about her garden or life in Orleans, just to open a dialogue.

After spreading out the materials on the table, and talking a little bit about what each could be (i.e. the plastic mesh could represent a chain link fence) I noticed hesitancy from everyone in the group to actually pick up and start working on their ideas. It was my initial intention to not even make a model. I had been trying to leave as much of my creative input out, and remain objective and informative instead. I did not want to influence the group by showing them my idea of what I thought the pavilion should look 
like. I was afraid that whatever I produced would be seen as the 'right' or 'best 'answer.

I had also been trying my best to not think about the design of the pavilion on my own time. This proved to be especially difficult. My nature is to think about design solutions, to visualize and to problem solve (hence why I am in architecture). As I lay in bed at night, I had to practice meditation to keep my mind empty, and didn't allow myself to pick up a pencil to sketch any ideas. I knew that if I let my design formulate I would be more likely to influence the group's design, even on a subconscious level.

However, at this point, I decided to intervene, to move the group onward from the current stalemate. “Ok, I'll show you how to make an architectural model without actually thinking about it." $(11 / 22 / 1,17: 30)$ What I wanted to convey is that these were to be quick, initial, instinctual iterations of the pavilion, nothing final. Gina had mentioned earlier that her husband was a model train fantasist, and that their basement was filled with exquisite models. I think that this was what the group had in mind when I talked about making models.

As I was quickly gluing my sketch model, I tried to keep the participation going by confirming my design decisions with the group, using 'we' statements and reconfirming what the group has previously stated. "We want to drop at the back, to keep the sun out, right? And we want people to be able to walk under it." $(11 / 22 / 1,19: 20)$

However, what I was hoping wouldn't happen, began to happen. As I was creating the model, the group was engaged in what I was doing and really liked it. I had made a triangular form and I suppose nobody in the group had thought of that, so they were surprised and rather delighted with the idea. "Oh I like the triangle! ...I was thinking 
about that today, about how boring it was going to be just a rectangle over a picnic table, but this is really nice, I like the idea." Gina $(11 / 22 / 11,20: 30)$

Then the group started to infer that we should just go with, or work on the model that I was creating. I purposefully ignored their reaction and tried to get them back on track by saying: "So this is what we're doing today: get some sticks, try not to burn yourself, and go nuts!" $(11 / 22 / 11,21: 30)$

The group began quite readily working on their own models and lots of laughter ensued. I initiated and tried to incorporate some discussions that I felt were relevant to our project. For example, we discussed how our early education influenced whether or not we thought that we had artistic talent; how realism seemed to be only valued form of expression. Basically, if you couldn't represent things realistically, then you weren't artistic.

About half an hour into the meeting John arrived, and instead of taking the lead myself, I asked that one of the participants bring him up to speed. Nan quickly volunteered, and did a very good job outlining our goals and constraints thus far. I interpreted this to mean that Nan was invested in the process and was confident in what we were trying to achieve.

There were times when I felt that I could have asked an open ended or leading question instead of providing a direct answer. For example, when John asked what the pipe cleaners were for, I responded that I thought it would be good to represent something curved, like a pve pipe or glu-lam arch. I could have responded, "to make something curved," and then asked "what's an example of a curved building material or structure?" 
After about 20 minutes of constructing, I presented my pavilion model to the group, basically to show them again 'how to' do something that they hadn't done before. After Gina, Nan, and Pat presented their models to the group we began to consider how the constructions would best be positioned on site in relation to the sun. When discussing controlling the shade, Pat brought up the idea of a rolling screen, 'Japanesey' style. I instantly began to formulate an argument in my head as to why anything Japanese wouldn't work and would be against the design principals that we had set for ourselves. I had put some forethought into the topics that I thought might come up, for example why we weren't just buying a Wal-Mart gazebo, but I hadn't prepared for this one. Luckily, within a few moments the idea was nixed because the group felt that anything that required adjusting or was moveable would be easily be broken.

I had done some pre-emptive research on sundials and the specifics of our site because I thought that such an element would be interesting to incorporate into the garden pavilion. I hadn't brought it up, and wasn't sure that I was going to, because it was an idea that I had hoped for. However, a candid talk about one thing or another led to the idea of an obelisk on site that could tell time. At this point I felt comfortable letting the group know that I had done some research if they were interested, but it didn't come up again.

Around the halfway mark of the meeting, I began to realise how discerning the group had become. The members were really embracing the idea of using non-conventional building materials, and even shot down one of my suggestions. Pat suggested that one way to make John's model work better, would be to use fabric to make it more tentlike. When I sang the Fabricland jingle, as to indicate that that's where we could buy 
fabric, the group quickly reminded me that that was not in keeping with our strategy for inventive use of materials or recycling....! (11/22/1 1,01:10:40) Also, when John thought of using PVC pipe to span between the posts I could see that thinking outside the (WalMart) box was happening.

"Cause I wouldn't think that we would need the pipe as a pipe, we need it as something that could hold up [the light fabric]." John (11/22/11, $1: 19: 54)$

As we continued to brainstorm materiality for the 'tent' idea, John suggested we look to see if any fencing company's had any left over posts that we could use for the main structure. This was one of the key suggestions that ended up in the final design.

Playing devils advocate, I remarked that the canopy, if 'solid' wouldn't produce any of the shadow patterns that the group had liked so much in our precedent research, but if the canopy was perforated, it wouldn't be rain proof. The group tossed around ideas of linking inner tubes, using chain link fence with woven hose, military netting, CD's or flattened tin cans as shingles to create interesting shadows. The rainproof idea was quickly deemed unimportant by the group, as they said that whenever it rained, they went home or if it was a brief shower, they would take cover in the tool shed. To me this seemed like a poor decision not to include a sheltered area since we were building a canopy anyway, but I didn't push the issue. It was however, something that nagged at me and that I strongly disagreed with.

About half an hour before we had to close the meeting, I tried to summarize what I thought was our best and simplest idea so far: a tri-post structure with a canopy that was angled to provide maximum shade from above and a panel on one side to block the setting sun. I told the group that at this point, I felt that I had enough information to 
work with, meaning that I could go away, work independently and re-present the ideas back to them more fully at another meeting. However, Gina turned the meeting back to discussing the models again and we continued to talk about materiality, durability, ease of repair and safety. After another 10 minutes, I tried again to get the group's consensus about the next step as I felt we weren't getting anywhere because we didn't have enough information.

\begin{abstract}
“Alright here's what I am thinking... it's almost 8:30... I am thinking that, I should take what we have now, these models, and then... take them a little bit further in terms what would they actually be built out of, what dimensions would they actually be, and figuring out all these things that we are having troubled figuring because we don't have the materials in front of us; you know like would chain link and a rubber tire actually work? Because you can't tell until you have it actually in your handstrust me!"
\end{abstract}

$(11 / 22 / 11,01: 40: 20)$

When going through our design guidelines (see fig.19) we came upon another issue that I didn't agree with. Gina had stated that all sides of the pavilion had to be high enough to walk under. John and I both questioned her reasoning because we didn't feel that all sides had to be over 6', that it could still be designed safely. My response this time was to use humor to disagree, but not harshly. I made a joke pretending not to understand why we couldn't have something sharp poking out at eye level.

Gina is the group chairperson and manages the insurance policy for the garden; John reasoned that if people had to be able to walk under the new canopy, then the shed on site would have to be removed because he couldn't get in without hunching over. A long discussion ensued over onsite hazards and safety for visitors other than the regular gardeners. Gina concluded that she would look over the insurance papers and get back 
to the group with the specifics.

As we continued to read through the design guidelines, I realized that I had added 'multifunctional' to the list of design 'wants' not because the group had stressed that point, but because that is something that is on my own design agenda. Another idea that I let go was to have built-in, or at least corresponding custom outdoor furniture. I felt that using factory standard picnic tables would detract from our self styled pavilion, that we would be missing a great design opportunity. The group however, was happy with their ready to assemble and affordable picnic tables.

The next discussion item was "moveable, no permanent footings.' Gina had specifically stated that there was to be no concrete on site. This meant that we had to keep everything fairly light and were going to have to come up with a creative structural solution, especially if the pavilion was to be left up all winter. Concrete footings were undesirable because they would disturb the site, were to some degree toxic, and there was uncertainty of the lifespan of the garden itself. The land belonged to the City of Ottawa, which had the final say regarding the continued existence of the community garden program. We discussed a variety of structures- logs, the 'e-z spike,' a commercial product for staking down fence posts, and the like. Gina had emailed me the advertisement and I agreed to discuss it with my thesis advisor, but didn't think that it would be suitable in this application.

Gina probably did as much of the urging of the group to move forward and stay on task as I did, and when she called the meeting to a vote out of the blue, I was relieved. I felt at a loss, since I had already suggested twice that I had enough information with which to move forward. Going with my gut, I declared that I was going to leave the vote 
up to them, to let the group make the final decisions. The group had done a very clear and thorough job of identifying the issues that were important to them and I didn't feel at all like they were missing anything or weren't ready to move on. John asserted that maybe we should pick 2 options, because if I only developed one and it proved not to be feasible- for example cost wise- we would be

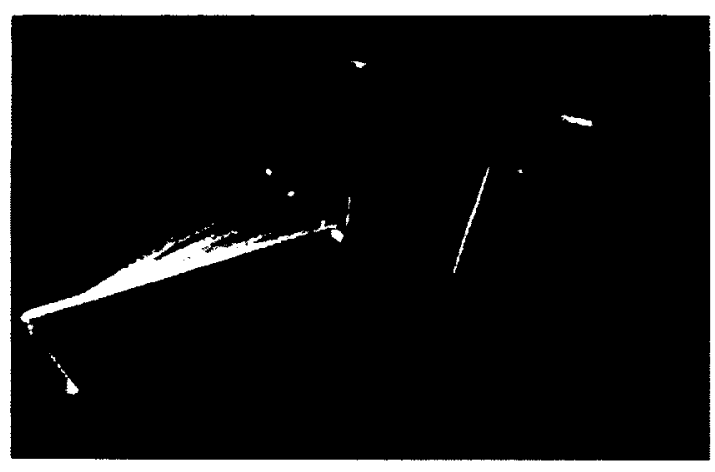

Figure 21: the two selected sketch models back at square one.

Just as the meeting was about to close, a key moment occurred, that proved to me that the group had really reached a deeper understanding of architecture and participatory methodology. While discussing material options Gina voiced the following opinion:

"...and I think whatever we pick is really important, because we do want to make an archway, going out into the fruit garden, the orchard, and whatever we pick for our material we can mimic that; like if we use chain link on the top, of one of these, we can use it as the arch in the other one, because vines will be growing over it, to keep that the same style throughout." (11/22/11, 01:56:04)

I was elated. I felt as though the group had really been affected not only by the project but by the process; that this process would have an impact, not only on the immediate task at hand - the shade pavilion - but would also be perpetuated in a larger context and in their lives as they continued to navigate the built world around them.

The meeting concluded with the decision that I would further develop the two selected sketch models and present them back to the group for a final review. This was the turning point from group to independent work. The traditional model (see fig. 19) of 
architect-client relation had begun, I was now on my own to take the input of the clients, work on the design, and bring it back for approval.

This seemed like a natural direction to take because we realized that we couldn't go any further without material testing, which would have meant another workshop. No doubt, a materials workshop would have been equally productive, but given the time constraints, the additional workshop was deemed unfeasible.

Throughout the process, there were only 3 instances where my architectural knowledge was needed. Two questions were raised about the stability of a tripod structure, and the resistance of the pavilion to wind forces. I was able to respond to both. However, the third question - about frost heaving in clay - I actually didn't know the answer to, and said I would look into it.

I contributed my subjective opinion and objective knowledge fairly equally, however was never asked for the former and only eight times for the latter. This inequality surprised me; I thought that my design opinion would be sought out at least once during the two and a half hour session! Perhaps this was because I offered it as much as I did my objective knowledge. Even though I made a concerted effort not to 'direct' the design, and felt that I wasn't doing so during the process, upon reviewing the tapes, I admit that I had more input than I intended.

Figure 22: Response Control Assement, Orleans

\begin{tabular}{|l|l|l|l|l|}
\hline Pts. & Response & Specifically & \# of & Example: \\
\hline & & $\begin{array}{l}\text { Scholastic or knowledge } \\
\text { from previous architectural } \\
\text { projects }\end{array}$ & 6 & $\begin{array}{l}\text { Properties of chain link fence; will } \\
\text { three posts be enough }\end{array}$ \\
\cline { 3 - 6 } & $\begin{array}{l}\text { When asked adds } \\
\text { new objective info }\end{array}$ & Material Sourcing/resources & 2 & Where to get inner tubes, fencing \\
\hline
\end{tabular}




\begin{tabular}{|c|c|c|c|c|}
\hline \multirow{3}{*}{1} & \multirow{3}{*}{$\begin{array}{l}\text { Adds new } \\
\text { objective info }\end{array}$} & $\begin{array}{l}\text { Scholastic or knowledge } \\
\text { from previous architectural } \\
\text { projects }\end{array}$ & 19 & $\begin{array}{l}\text { Imparting info regarding footing } \\
\text { specifications, how to make a model } \\
\text { etc. }\end{array}$ \\
\hline & & Material Sourcing/resources & 1 & "At school we have a metal shop." \\
\hline & & $\begin{array}{l}\text { Reminds group of something } \\
\text { that they have already } \\
\text { agreed on. }\end{array}$ & 5 & $\begin{array}{l}\text { "The downside to it you wouldn't } \\
\text { have those beautiful shadows. (that } \\
\text { the group already indicated that they } \\
\text { liked) }\end{array}$ \\
\hline \multirow{3}{*}{1} & \multirow{3}{*}{$\begin{array}{l}\text { Asks for } \\
\text { clarification }\end{array}$} & $\begin{array}{l}\text { Did you mean? } \\
\text { Do you think? }\end{array}$ & 5 & $\begin{array}{l}\text { "Would you think that people would } \\
\text { fit through those slats?" }\end{array}$ \\
\hline & & Is this right? & 2 & $\begin{array}{l}\text { "So we're ok with it being centred or } \\
\text { off to one side?" }\end{array}$ \\
\hline & & Repeats or summarizes & 6 & \\
\hline \multirow{2}{*}{1} & \multirow[t]{2}{*}{ Asks questions } & $\begin{array}{l}\text { To get participation, because } \\
\text { I want them to consider a } \\
\text { design decision/factor }\end{array}$ & 10 & $\begin{array}{l}\text { "...for the substructure of these } \\
\text { scales, would we need this much } \\
\text { structure?" (it would obviously not) }\end{array}$ \\
\hline & & $\begin{array}{l}\text { Because I truly don't know } \\
\text { the answer }\end{array}$ & 2 & Where could we get old gazebos \\
\hline 2 & $\begin{array}{l}\text { Direct compliment } \\
\text { on design }\end{array}$ & & 3 & $\begin{array}{l}\text { "I like the criss-cross pattern" } \\
\text { (regarding Nan's model) }\end{array}$ \\
\hline 1.5 & $\begin{array}{l}\text { When asked, } \\
\text { adds new } \\
\text { subjective info }\end{array}$ & I think, I like & 0 & \\
\hline \multirow{4}{*}{2} & \multirow{4}{*}{$\begin{array}{l}\text { Adds new } \\
\text { subjective info }\end{array}$} & I think, I like & 8 & $\begin{array}{l}\text { "I am not as formal, but I think that } \\
\text { you guys are very formal." }\end{array}$ \\
\hline & & My design opinion & 1 & $\begin{array}{l}\text { "... It's the two of them that really } \\
\text { give it the dynamism." }\end{array}$ \\
\hline & & $\begin{array}{l}\text { Suggest design or design } \\
\text { elements }\end{array}$ & 10 & $\begin{array}{l}\text { "I could see using some recycled } \\
\text { wood from the palettes and some } \\
\text { new wood for contrast;" }\end{array}$ \\
\hline & & $\begin{array}{l}\text { To initiate a discussion that I } \\
\text { thought was relevant. }\end{array}$ & 1 & $\begin{array}{l}\text { Discussing school's influence on our } \\
\text { creative ability }\end{array}$ \\
\hline 3 & Agrees & & 8 & "Yes, that makes sense." \\
\hline
\end{tabular}




\begin{tabular}{|c|c|c|c|c|}
\hline \multirow{3}{*}{3} & \multirow{3}{*}{ Disagrees } & Overtly & 2 & $\begin{array}{l}\text { "I don't think that's making best use } \\
\text { of that wood, I think that's stretching } \\
\text { it; trying to make it something that its } \\
\text { not." }\end{array}$ \\
\hline & & Ignores & 1 & $\begin{array}{l}\text { When they said that we should just } \\
\text { work on my model, I quickly moved } \\
\text { on, because I wanted the group to } \\
\text { proceed with their own models. }\end{array}$ \\
\hline & & Indirectly & 1 & $\begin{array}{l}\text { Disagreed with the 'height hazard" } \\
\text { Gina indicated; used joke/sarcasm; } \\
\text { "we can't just have something } \\
\text { sticking out at eye level?" }\end{array}$ \\
\hline 4 & $\begin{array}{l}\text { Refuses to further } \\
\text { participate }\end{array}$ & & 0 & \\
\hline 4 & Takes full control & & 0 & \\
\hline
\end{tabular}

\subsubsection{Post Workshop Summary}

The next step was for me to take the workshop results and develop them into buildable projects. My plan was to have the designs available for the group to assess over the holidays in December. This took longer than I thought. I found myself trying out every option that was mentioned in the design sessions as well as options that I thought of on my own. I realise that my perfectionism and eagerness to impress the group motivated me to go overboard on looking for the perfect solution. For example, the group was content with using new lumber as opposed to the stockpile of skid wood that they had on site, however, I felt that If I found a way to use the'free' wood, I would be happier with the outcome. I spent a lot of time following leads like this to come to no avail.

The next thing that unnecessarily consumed my time was a simple miscalculation that I didn't catch until I had nearly completed the design, detail drawings and began to price the materials. I had based the design on John's sketch model, a simple timber structure that by my calculations was angled and sized to provide optimum shade for 
a picnic table for most of the day in the heat of summer. However, I realised that when I was looking up the price of timber at the required length from our local lumber store that they didn't carry that length. In fact, engineered lumber or truss would be the only options for that span. These options didn't fit any of our parameters that we had set for the project - budget being the most obvious one.

Another lesson that I learned was that using non-traditional construction and materials - even though there are many benefits - requires more design time because there are no existing standards to use as guidelines. Timber frame construction has been documented and standardized in all aspects; all the answers are easy to find in publications in print and online. Non-traditional building materials and assemblies need to be tested and predictions made as to durability and longevity. In our case, we didn't' have the time to do testing for these variables. Many ideas that we came up with had to be discarded because we couldn't predict how long the components would last and what property changes the materials would go through over the long term.

There is definite value in exploring re-use and non-conventional building materials, however additional time and resources must be allotted to the time line of the project.

When I missed the holiday deadline, I was afraid of loosing the group's momentum and trust. I wrote a letter and tried to convey that even though I was behind schedule I was still $100 \%$ dedicated. When I got an email from Gina saying that she probably wouldn't be available for the next meeting and that one of the previous participants couldn't continue either, I felt my fear of loosing the groups' interest had come true. However, I was certainly not giving up and I pushed through to complete 2 design options for Gina and the group. to privately review: "Flight" and "Bloom," both tent like structures using 
recycled vinyl banners and 3 chain link fence posts and hardware.

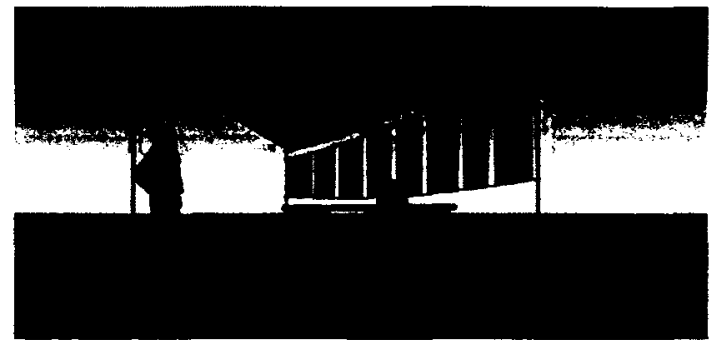

Figure 23: "Flight Option"

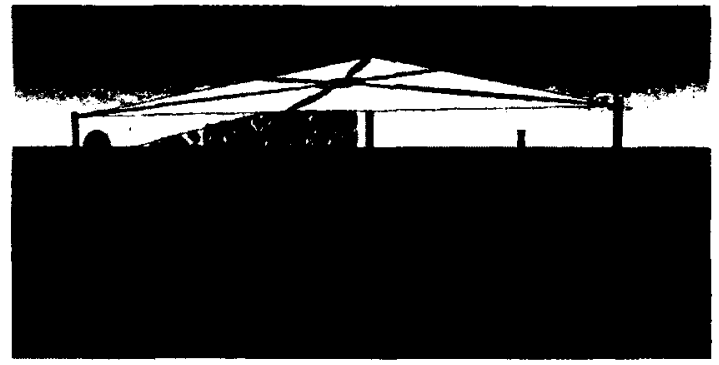

Figure 24: "Bloom" option

Gina emailed me right back, saying that she and Marco (her husband and Operations Manager for the garden) both loved it... and could we do two? I said we could do as many as they wanted and was really pleased that they felt that the design had come out so well. When I asked Gina why the group hadn't chosen the 'bloom" options, she said that the geometry of the canopy pattern looked too complicated and that the side panel looked too much like military netting. I felt that we were back on track and met a few days later to discuss the logistics of the construction of the project. There was still a decision to be made about the type of hardware that we wanted to use. When they responded with whatever is less expensive, I felt that I had to further explain that a change in hardware also affected the future maintenance schedule; I was surprised that they ultimately selected the more expensive option that would be easier to repair. However, I felt that they had considered the factors and that they were making the best choice for themselves. No intervention required.

The goal of the meeting was to finalize some detail decisions and divvy up the work load. Gina had sewing experience and was going to take on sewing the vinyl canopy and side panel. John, the VP, was in charge of grommeting and hardware assembly, and I was responsible for the structural element coordination and providing each with moral and technical support. I felt really grateful to be working on a design that was thoughtful, 
beautiful and drew on the groups' strengths. I think that the personal involvement in the design - and now the construction - dramatically reinforces the ownership that the participants feel toward the pavilion.

As a 'test' of this theory, I am anxious to do post occupancy interviews with the group to see if my hunches are right. I will use an outside source to conduct the interviews to ensure as much objectivity as possible. I am curious to know whether they will say "we" or "Lee" when telling the story of how the project came to be.

At the most recent meeting, the Spring Annual General meeting, we took the opportunity to share the project with new members looking to secure a plot, as well as returning members who were eager to start the season. I created two presentation panels and brought an example of the hardware assembly. I had three goals for the meeting. The first was to recognize and thank the participants among the greater group for their contributions. The second objective was to introduce the project to gardeners who hadn't heard of it before. The third, and most important was to get more people involved in the build day - especially anyone who had experience with fencing or footings. A couple of men offered their experience and support. I was pleased that they were both new members. This is an example of one of the 'side' benefits of the pavilion. Besides providing much needed shade, it was bringing people together, sharing experiences and forging a stronger community. At the end of the meeting Gina asked if she could have the presentation panels to frame and that she really wanted our 'book' to be professionally bound and signed by the group members.

The build date was bumped up to the second weekend in April because of the very mild weather in Ottawa this winter. As of March 20, 2012, Gina has completed all of the 
sewing and John will be done the grommeting by the end of the week. There is much to do within the next three weeks to prepare for the build, but the skin and structure will arrive onsite, ready for installation.

\subsection{CASE STUDY 2: Greely Community Association}

\subsubsection{Intro}

The Greely Community Association (GCA) is a volunteer organization run by a core committee of President, VP, Treasurer and Secretary and several sub-committees including recreation, transportation and development. They liaise with various groups and the City of Ottawa to improve the quality of life, advocate for community interests and coordinate annual events such as the Winter Carnival and Canada Day Celebration. Greely is about $20 \mathrm{~km}$ south of Ottawa; the population is approximately 8,000 and is one of the fastest growing suburbs.

\subsubsection{PRE workshop summary}

The President of the GCA responded to my initial email indicating interest, and asked if I could attend their business meeting the following Wednesday. Again, I brought Timbits and handouts. This time I decided to read through a couple of examples to preemptively answer questions that had come up in previous meetings.

An example of a community garden beside a church ${ }^{39}$ stimulated a discussion about where the project would be built. Who's land would it be on? How could it be financed? Would the city donate or lease some land? We tossed around ideas and came to the conclusion that there was potential for a project to develop, if not permanent, at least

$39 \quad$ See Appendix B 
something temporary or event specific like a skate shack for the outdoor rink or a stage for Canada day.

A persistent concern was that Greely was developing so quickly that the character of Greely was getting lost. For many years the Association had been advocating developing the village core, but growth was happening everywhere but there. Frustration over this issue became apparent when a member questioned whether a thesis experiment like this was really going to change anything? I felt quite discouraged until another member piped up that at least it would be something new, and that if the City wasn't involved, chances are it would be built! This lightened the mood a little bit and a discussion ensued about how small things can and do have big effects. The group was very gracious, friendly, and was clearly passionate about its town. As I left the meeting that night, I felt that they would be great group to work with, but I wasn't hopeful that they would be interested.

Just as I was pulling into Ottawa, my phone rang. It was a member of the group who wanted to say that they had had an after the meeting meeting and that they think that they had a project that might work. Howard, the group treasurer, said that he and a couple others were really interested in resurrecting some of Greely's history by building a replica of the former toll gate. Greely's origins date back to its strategic location on the stagecoach route between Ottawa and Kingston. Howard expressed that "although Greely had a lot of characters, it didn't have a lot of character" and thought that doing something to commemorate Greely's history could start to get people interested in and be a catalyst for other projects that would anchor the community back in the historic village core. This sounded like a great project to me. The right scale, it was addressing an important community issue and it had support to go forward... but the one thing that I 
knew that wouldn't work is that they wanted to build a 'replica.' Building a replica leaves out an essential ingredient: the design component. After discussing this difference with Howard, I asked him to write up a proposal for the project to discuss with my thesis advisor.

Through phone conversations and email Howard and I were clear that the project could include a toll gate replica, but that that wouldn't be the whole project; that we would brainstorm with the two other members of this new ad-hoc group, Lori and Brandon, to come up with an architectural response to bring to light Greely's unique character. With this ground work laid, I felt comfortable moving forward with Greely as the second and final group to be chosen to engage in the exploration of collaborative architecture.

\subsubsection{Workshop\#1: Analysis \& Precedents}

PART ONE: The precedent analysis was actually spread over two meetings. The first meeting was specifically dedicated to discussion of road side spectacle and replica's vs. architecture. We looked at info booths from around the world, in different contexts and found that most were one liners and more spectacle than thoughtful. We kept notes about our thoughts on the precedents, what we liked what we didn't and what we could see working for our project. An interesting find were two different info pavilions for the same park. One was a log cabin style booth, the other was a contemporary wood and glass structure; clearly demonstrating that there is more than one architectural response to any given context. The group had made the leap from road side attraction to architecture, but still wasn't sure what exactly was the architecture trying to express. It is difficult to evaluate the success of an architectural project without knowing what the project was trying to achieve or communicate. Looking at some of the more 
contemporary structures together I realised that while the group appreciated them visually, they weren't connecting with the intent. This meeting concluded with a consensus that for the project to be eye-catching and attract the interest of passers by, it was going to have to be a strong, simple form, one that would be more timeless than trendy.

While images from the internet and photos in books provide a certain amount of food for discussion, they lack the depth of understanding that can come from knowing the history, context and architectural intent of the projects. Knowing that the group wanted their project to be thoughtfully constructed and meaningful, again I showed them some of my third year collaborative design projects so that when they had questions about intent of any kind I was able to provide an explanation. This proved to be very helpful to the group in being able to ask specific questions about the architecture and as group discussing the architectural intentions and process.

At the end of the meeting I assigned the group some homework: they were to gather any precedent material that they felt relevant to the project and to record any ideas of what they thought the pavilion should be like.

PART TWO: I was pleased and surprised that both Lori and Brandon had drawn out their ideas! They were decidedly different and both very thoughtful as to the elements that they thought were important. I used the strategy of open ended questions and repeating back their ideas to them to draw out their intentions and to generate discussion. This process was very similar to the Orleans design session when we discussed the members' sketch models. Brandon's sketches had a more monumental and sculptural approach, whereas Lori's drawings contributed more to the understanding of how she wanted people to feel at the pavilion. 


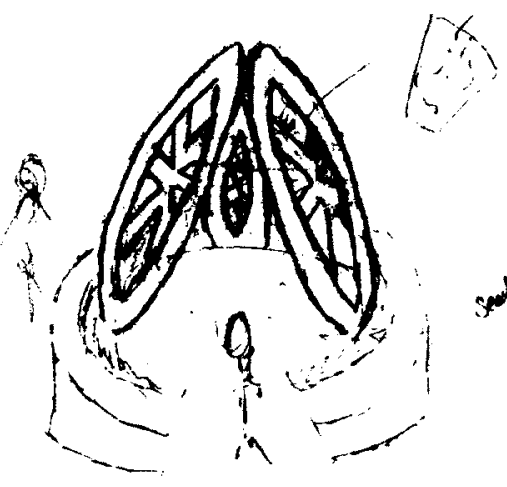

Figure 24: Brandons Sketch

Knowing that the group responded well to precedents for which they might have an appreciation of the architectural intent, I came up with the idea of looking at the series of Canadian Expo Pavilions. Over the years the pavilions have morphed and changed but all have tried to express something essential about Canada to the world.

Being familiar with the intent, the group felt more comfortable critiquing these projects, and despite the strong, un-conventional architecture, had no qualms sharing what they thought was successful or not.

With the understanding and analysis of the expo pavilions, the group began to grow more animated about their own project. Howard then excitedly drew the group's attention to a postcard of the Canadian "Katimavik" pavilion from expo 67.

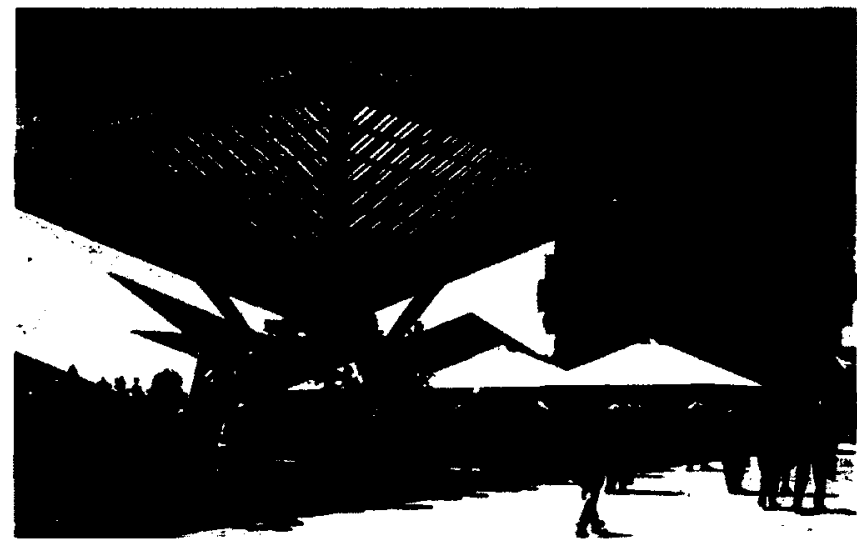

Figure 26: Expo 67 Postcard
I was excited that he was excited! Finally- something that had caught his eye! Something so beautiful, so striking yet such a simple shape was exactly what we needed to go for! However, a few seconds later I realized that he was talking about the white tents in the foreground....

That we could set up some open-sided tents and have historic displays underneath. 
With this suggestion, I felt that we had gone two steps forward, two steps back. Nearing the end of the meeting, I suggested that I take the ideas that the group had put forth and try to combine them into something more architectural. Even though we were pressed for time, I felt that the group needed a solid design intervention with which to move forward. After the meeting, I felt very conflicted. If the group wanted something generic, then why push? If it was ok with them, then why intervene? I decided that even though the tent-like structure seemed to be an acceptable possibility, , everything else that we had talked about, dreamed about and were passionate about deserved to be addressed; that in order for the group to make that architectural leap, I had to take the lead.

The design that I worked on was to be a culmination of the group's ideas thus far. It was not meant to be an end, but rather a beginning, to discuss what their ideas could look like architecturally - besides a tent and displays underneath. This led me to act fast, on my own, to create the simple SketchUp model that I proposed at the next meeting; a starting point to generate ideas as a group; an amalgamation of Brandon's wheels, Lori's comfy gazebo and Howard's simplicity of form.

Due to unforeseen circumstances, the pavilion that I had independently worked on was revealed to the three different members at three different meetings. Critique and discussion was generated, but the unity of the group suffered, I didn't feel that we were all on the same page. But we forged ahead, looking forward to when we would all work together on the first 'real' design charette.

\subsubsection{Workshop\#2: Design Charette}

Feb 29th 2012, Carleton University, 7-930pm, Lee, Howard, Lori

The objectives for this meeting were to discuss the pavilion design, create a site plan, 
look at several different layout options and choose one with which to go forward. We wanted to have enough information to formally present the plan to the city of Ottawa. Howard intended to bring a proposal to City Hall with visuals and written description by the end of March..$^{40}$

The first part of the meeting centered around a discussion of Modern art; Howard had brought in books about the Group of Seven, Modigliani and Jack Bush and talked quite passionately about the work, especially that of Bush. He spoke of the movement displayed in "Chopsticks" and how the simple abstraction can tell a story. I was hoping that I would be able to translate this understanding into architecture. Strangely enough, however, Howard was the most 'practical' when it came to the info pavilion we were working on.

While waiting for Brandon to arrive- who unfortunately didn't make it to this meetingHoward asked if I will be writing about group dynamics and personalities. I let them know that although I find that very interesting, I am not a sociology major, but will be including information that leads up to the design decisions.

Howard continued by informing us that the Greely Garden Association would probably want to be involved in the landscaping aspect of the project. Also, that he had found some new information about the elusive toll-gate. No one, including the Vernon Museum up the road, the Ottawa Public Library Ottawa Room and Archives, local history buffs or descendants of the original gate operator has thus far been able to locate a photo of the gate - let alone agree on where it actually was. Howard did find a dimensioned drawing of the toll gate by Mike Daly, a local history buff, who drew it according to someone's description of it. I felt uneasy about choosing one person's opinion of history $40 \quad$ See appendix D 
over another's, but because I hadn't plans to do the footwork that would be associated with further investigation, I decided that if the 'group' was comfortable with it, to move on. It's not about the design per se, so I let it go.

Realizing that Brandon was probably not coming, I got Howard and Lori started on the site plan. I printed out a 1:125 satellite plan on multiple sheets of letter size paper. I asked Howard and Lori to assemble the plan, cover it with tracing paper and to map out the main features of the plan-streets, tree lines, fences, hydro poles etc. I could have done this myself but they enjoyed doing it and it simplified what issues we needed to consider as we laid out our design. Howard was eager to understand scale conversion to figure out the basic dimensions of our site and calculate total area.

Next we discussed the info pavilion that I had worked on at home and brought to the last meeting. Lori hadn't made it to the last meeting so she hadn't seen it before. Howard pointed out that it's a semi circle, like a wheel. I reinforced that it was something that I had done quickly, just a starting point; because even though it was a culmination of their ideas thus far, I felt that it still needed more group input.

Howard is regularly forthcoming with critique, but for Lori to participate was a sign to me that she felt ownership and was well versed in the project. She even offered a design alternative to satisfy Howard's critique of "The things coming in at an angle." The following discussion ensued without prompting or intervention from me:

$(02 / 29 / 11,00: 11: 20)$

$\mathrm{H}$ : The only thing that I don't like about it is that the rain can get through and stuff, so it would be nice if we can put something solid over it

L: Well, actually you can let the rain get through and just put plexi over the- 
$\mathrm{H}$ : But then where will people go sit if it rains? They'd probably like to use these benches, right?

$\mathrm{L}$ : [sighs in somewhat disagreement]

$\mathrm{H}$ : -but, you've got your benches right, remember you talked about that; we've got something really nice.

L: $\quad$ ya

$\mathrm{H}$ : The only thing that I don't like, that I looked at, l'll tell ya the truth was; I really liked except for the roof, and the one thing that I don't like is these things coming into the signs. For some reason they don't do it to me.

Me: where? what?

$\mathrm{H}$ : the things coming in at the angle

L: $\quad$ Oh the spokes

Me: the spokes

$\mathrm{H}$ : For some reason they don't do it to me; whether it was supposed to represent a wheel or not, they just don't seem to make it-

$\mathrm{L}: \quad$ well, maybe if there were more spokes?

$\mathrm{H}$ : Maybe, if we had more spokes, maybe that would be a good idea, because as it is right now,

L: Because it would-

$H$ : I just look at it and go ewwww...(disapproval)

But anyway, what I thought to do, would be to put it in the middle is where the map is.

L: ok

$\mathrm{H}$ : and super imposed over that is today's roads, so people can figure out where they were, and would say on the left, we do generalized stuff,

L: uhuh

$\mathrm{H}$ : cause this was a transportation hub; and on the right we talk about the toll booth; so we go from something general, to a map, to something specific

$\mathrm{L}$ : it covers all the things that we want it to do. 
The discussion of how to address the fact that we didn't really know what the toll gate looked like reemerged. After Howard asserted that it didn't matter where or what the toll gate looked like, because we are only making a replica, I decide to suggest a way to approach the issue from a different angle:

$(02 / 29 / 11,00: 17: 33)$

Me: But what I find is interesting, about all of this is that there is such a varied and mysterious history and I think that that can be part of the story that we're telling. Cause we don't know, and we don't the answer, and that's ok. That's cool, I think. L: there's nothing better than a little bit of mystery.

I feel good about this, but not sure that Howard necessarily agrees. Shortly after, I again assert control/direction on the design, but this time I didn't even realize it until after. I assumed that we would be keeping the buffer zone of vegetation between the adjacent back yards and the west edge of our site for privacy and noise. To me this was just a given, however, it would have been an opportunity to ask instead of assume. Howard also corrected my terminology when I used the word 'hill' instead of 'berm.' Am I not supposed to be the one with the extended vocabulary in this area?!

Almost an hour into the meeting, we started to look at possible configurations for our 5 elements: the sculpture, pavilion, toll gate, parking and picnic area. Earlier in the week Howard had sent me an email that described the location of things on the site in great detail. I asked him to sketch this out on the trace as best he could. When he was hesitant, I assured him that his was just a starting point, not to worry too much about dimensions; that we were just trying to get an idea of his vision. However, he further hesitated and said to me:

"This is where I need you to rough it out for me; maybe this is 
something you can do, because you have more artistic talent, artistically inclined."

$(02 / 29 / 11,00: 54: 00)$

I begin to resist and then quickly'give in.'Drawing-or expressing their ideas with a pencilseems to be a daunting prospect for most people. My experience thus far with both groups is that picking up modeling supplies like wood or clay is a lot less intimidating than picking up a pencil. Howard and I sketch out his design on the trace paper as per his real time direction and what I gathered from his email. He is quite satisfied:

"Ok, that's perfect! That's the way that I would have drawn it."

$(02 / 29 / 11,00: 56: 00)$

After our sketching was complete, Howard asks Lori and I what we thought. I began to say "I like..." but caught myself and repeated back what he has said instead offering my design preference.

$(02 / 29 / 11,00: 57: 25)$

Me: I like... What I am seeing here is a really strong axis here, right? Between your entry to the parking and your exit to the parking, to get to this kinda like goal or something, but you have to take this meandering path around to get to it, there's no direct route, so that creates interest for the visitors, and is visually a nice kind of-

$\mathrm{H}: \quad$ take it in slowly

Me: -a journey, ya

$\mathrm{H}$ : enjoy it. Some stuff to look at as your getting to here, there's a few other things here.

The discussion continued without my prompting or intervention about more key design and site issues such as trees and shade, road allowance, location of picnic tables, and 
division of labor regarding the park maintenance. Lori suggested some different parking configurations and I responded that with my experience the city would have its own ideas: "I bet you whatever we design they're going to change it anyways." However, the parking discussion continued and we used the site plan to visualize different options. The discussion ended with a discussion about the difficulty of changing people's routines. The new entry to the site will be a change for people who are accustomed to pulling over to pick up their mail.

With the parking more or less marked out, we set to work on scale models of the pavilion (me) and the sculpture (Howard). Howard's sculpture is a spin off of Brandon's sketch from a previous meeting. It actually started off as an idea for the info pavilion, but the group came to the conclusion that it was more powerful as a sculpture, and that adding historical information onto it would just clutter it up.

Howard taped together 3 binder rings and explained that in the 'real' sculpture there would be 4 circles, two smaller and two larger wheels, like the wheels of a carriage. The $4^{\text {th }}$ wheel would be implied on the ground by a circle that shows the cardinal points and direction to Bytowne and Kingston with mileage. This was Lori's idea to incorporate some history into the sculpture but not overwhelm it. The sculpture is described by Howard as:

"Like it's not abstract, but there is a little bit of a puzzle to it. And that's what I like about it, that the fact that, there's a little bit of a mystery to this thing."

$(02 / 29 / 12,01: 48: 12)$

To me this signified that Howard had picked up the concept of adding a little mystery to our project. He agreed that we didn't need to indicate that we had all the answers about 
Greely's history... and that it was actually more interesting that we didn't.

As I was making the quick sketch model of the information pavilion, Lori and Howard shared more of their feedback. They appreciated that there was air flow, that it had incorporated Lori's seating idea to make it both useable and beautiful, and suggested that I lower the roof from 13 feet to at most 10 feet.

We talked about the importance of community involvement, and how for example if Greely Sand and Gravel donated materials, then we should figure out a way to recognize their support of the project. Howard suggested putting a sign on the back of the info pavilion.

The second hour of our meeting was coming near and we still hadn't settled on the placement of the elements. Lori and I were more on the same page in terms of working with sight lines instead of a literal narrative to map out the park. I playfully but openly disagree with Howard and give my version of the design. Why did I disagree? I disagreed because I felt we would be missing one of our objectives to announce the entrance of the 'old town' if we didn't put the sculpture, the real eye catcher closer to the road.

\section{$(02 / 29 / 12,02: 04 ; 47)$}

Me: well what I am thinking of, is that this one is the eye catcher, you can't have it back here, it has to be, and that's the thing right-

L: $\quad$ it almost sparkles!

Me: this is the introduction (the gate) this is the gateway to the gateway park-

$H$ : ya ok, there you go, you're right, that's the Greely gateway, fair enough

Me: -and our signage on the piece of wood itself could be Greely gateway

The last 20 min of the meeting was my favorite part. I had been feeling a little 
disheartened that the design that we came up with didn't have that architectural magic. Something for me was missing. Nonetheless, the positive feeling related to the ripple effect of the project in the community remained strong. The information pavilion could become the trail head for the Historical Walking tour of Greely that was being developed by another GCA subcommittee. Howard suggested a 5k Greely Gateway Run and walka-thon as a possible fundraiser for the project, which could perhaps become an annual event or inspire a local running club.

$(02 / 29 / 11,02: 05: 12)$

$\mathrm{H}$ : this is gonna be the first real thing, that Greely has done, that's a real-

Me: it looks awesome!

$\mathrm{H}$ : I think people will happy to be part of this

L: $\quad$ this is, this is kinda Greely growing up

$\mathrm{H}$ : its like, lets take a stab, let's gather some of the history of this thing; and I would like to be a part of it; and once its done I can look back and go 'ya, I was a part of that, it was fun, I was happy I did it'

....As opposed to banging my head against the wall these people who's minds you can't change... sorry! (laughing)

L: $\quad$ it gives a sense of place, a sense of pride, a sense of purpose, a little information, a little fun, have a snack, and maybe the chip truck will still be there

$\mathrm{H}$ : well this is the first, then his thing plays into the walking, etc it all plays together; this is the first piece of what's coming next, it (speaking of community development)

$\mathrm{L}$ : essentially, this is the germ, and then someone else carries it from there

02:07:48

L: $\quad$ you know something though, hearing you say this, is exactly what I was hoping would happen; people would see this and say:"you know what we could do?" 
Me: yes

L: $\quad$ that to me is success! If you can just spark some imaginations and stuff, let's get people happy to be here!

The point was that we weren't going to change a whole community with one small project. However, there was a sense that for once, we could actually get something done. The small scope of our project made the outcome manageable, and physical results would be a testament to our determination. Momentum could grow from there. Architecture was being used as a catalyst to address community issues. This was a great discussion with which to close the meeting.

Listening to the audio recording and filling out the RCA confirmed my feeling that for the most part I stayed objective and played the role of the facilitator quite well during the design charette - except for the one aforementioned instance when I proposed that we reflect our intentions of creating a space of wandering and discovery by splitting up the pavilion. This suggestion was understood differently than I intended and I didn't take the opportunity to try and explain what I meant.

When I complimented a particular design element or move that a participant made, I consider that to be exerting control, or directing the design through positive affirmation. During this workshop I noticed that while I was being very complimentary it was more about being encouraging than agreeing with a certain design idea; it was for the process, willingness, craftsmanship and our progress that I praised the group.

My 'specialty' architectural knowledge was primarily needed for the 'how to' or instructional part of the workshop (label a site plan, build models, use a scale ruler etc) as opposed to specific knowledge relating to the design. I was asked directly once - the 
dimensions of a picnic table - and twice I offered my opinion regarding parking when I felt the discussion was going on too long about things that couldn't be decided that session. My design opinion was actually only asked for once and only half heartedly because I didn't even get a chance to answer. Again, I was surprised at how little I was 'needed' in the design as opposed to the process.

Figure 28: Greely Control Response Assessment

\begin{tabular}{|c|c|c|c|c|}
\hline Pts & Response & Specifically & $\begin{array}{c}\text { \# of } \\
\text { currences }\end{array}$ & For example: \\
\hline \multirow[t]{2}{*}{0.5} & \multirow[t]{2}{*}{$\begin{array}{l}\text { When asked } \\
\text { adds new } \\
\text { objective info }\end{array}$} & $\begin{array}{l}\text { Scholastic or } \\
\text { knowledge from } \\
\text { previous architectural } \\
\text { projects }\end{array}$ & 1 & -Dimensions of a picnic table \\
\hline & & Material Sourcing & & \\
\hline \multirow{3}{*}{1} & \multirow{3}{*}{$\begin{array}{l}\text { Adds new } \\
\text { objective info }\end{array}$} & $\begin{array}{l}\text { Scholastic or } \\
\text { knowledge from } \\
\text { previous architectural } \\
\text { projects }\end{array}$ & 2 & $\begin{array}{l}\text {-parking will be governed closely by } \\
\text { city bylaw. } \\
\text {-parking space size }\end{array}$ \\
\hline & & Material Sourcing & & \\
\hline & & $\begin{array}{l}\text { Reminds group of } \\
\text { something that they } \\
\text { have already agreed } \\
\text { on. }\end{array}$ & & \\
\hline \multirow{3}{*}{1} & \multirow{3}{*}{$\begin{array}{l}\text { Asks for } \\
\text { clarification }\end{array}$} & $\begin{array}{l}\text { Did you mean? } \\
\text { Do you think? }\end{array}$ & & \\
\hline & & Is this right? & 2 & - about size of pavilion and displays \\
\hline & & Repeats or summarizes & 1 & -Howards vision of outline \\
\hline \multirow[t]{2}{*}{1} & \multirow[t]{2}{*}{ Asks questions } & $\begin{array}{l}\text { To get participation, } \\
\text { because I want them } \\
\text { to consider a design } \\
\text { decision/factor }\end{array}$ & 4 & $\begin{array}{l}\text { Played devils advocate } \\
\text { "What other parking options are } \\
\text { there?" } \\
\text { Asked them about site lines, } \\
\text { placement, }\end{array}$ \\
\hline & & $\begin{array}{l}\text { Because I truly don't } \\
\text { know the answer }\end{array}$ & 2 & -include tollgate, and if operational \\
\hline
\end{tabular}




\begin{tabular}{|c|c|c|c|c|}
\hline \multirow{2}{*}{2} & \multirow{2}{*}{ Compliment } & Directly on design & & \\
\hline & & $\begin{array}{l}\text { General } \\
\text { encouragement }\end{array}$ & 6 & $\begin{array}{l}\text {-about their model building skills, } \\
\text { and outcome of site plan }\end{array}$ \\
\hline 1.5 & $\begin{array}{l}\text { When asked, } \\
\text { adds new } \\
\text { subjective info }\end{array}$ & I think, I like & 1 & $\begin{array}{l}\text { Howard asked my opinion about his } \\
\text { sculpture model, but I didn't get a } \\
\text { chance to fully answer }\end{array}$ \\
\hline \multirow{4}{*}{2} & \multirow{4}{*}{$\begin{array}{l}\text { Adds new } \\
\text { subjective info }\end{array}$} & I think, I like & 2 & $\begin{array}{l}\text { Regarding sumacs, } \\
\text { "I think that we've got the scale right, } \\
\text { you know what I mean, size wise?" }\end{array}$ \\
\hline & & My design opinion & 4 & $\begin{array}{l}\text {-suggests spreading the elements } \\
\text { out if we are truly trying to talk about } \\
\text { a journey } \\
\text {-that mystery should be part of it }\end{array}$ \\
\hline & & $\begin{array}{l}\text { Suggest design or } \\
\text { design elements }\end{array}$ & 2 & $\begin{array}{l}\text { "our signage on the piece of wood } \\
\text { itself could be Greely gateway" } \\
\text {-the pamphlet box will be integrated }\end{array}$ \\
\hline & & $\begin{array}{l}\text { To initiate a discussion } \\
\text { that I thought was } \\
\text { relevant or related }\end{array}$ & 1 & About bushes acting as a buffer \\
\hline 3 & Agrees & & 2 & $\begin{array}{l}\text {-About culling rather than clear } \\
\text { cutting } \\
\text {-Size of circles } \\
\text {-order of elements in park }\end{array}$ \\
\hline \multirow{3}{*}{3} & \multirow[t]{3}{*}{ Disagrees } & Overtly & 1 & $\begin{array}{l}\text { "well what I am thinking, is that this } \\
\text { one is the eye catcher, you can't } \\
\text { have it back here" }\end{array}$ \\
\hline & & Ignores & & \\
\hline & & Indirectly & & \\
\hline 4 & $\begin{array}{l}\text { Refuses } \\
\text { to further } \\
\text { participate }\end{array}$ & & & \\
\hline 4 & $\begin{array}{l}\text { Takes full } \\
\text { control }\end{array}$ & & & \\
\hline
\end{tabular}

\subsubsection{POST workshop summary}

After the workshop, Howard contacted Brandon to fill him in on the meeting. He was also going to be following up with some local businesses and artisans regarding their 
involvement with the project. Lori continues to research and narrow down the historical material that will be included in the historical pavilion. For the city of Ottawa meeting, I will be developing some presentation panels and editing the write up. Even though the project will not be built before my thesis defense, it will definitely be built. The timeframe will be clearer after our meeting with the City and securing the grant. The group had expressed some concern that I might not be around post graduation because I will be looking for work in other cities. At minimum, I have committed to provide the group with enough information to build the project, and drawings and images for fundraising and promotion. Hopefully, however, I will be able to continue on with the project through to completion and be there for the first annual Greely Gateway Run.

\subsection{Case Study Comparison \& Conclusions}

The first thing that surprised me about this experiment was the amount of response from the community. I was concerned that the interest in 'citizen participation' that was such a hot topic during Arnstein's era, had perhaps petered out. However, I was still getting emails in November and December from groups who wanted to participate - long after I had already started working with Orleans and Greely. Also, even though I don't believe that my particular thesis was a match for all the interested groups, it became clear that there were many groups who were interested in taking a more active role in their built environment. Support and interest in this project was further substantiated by an article in the local news, a call from $\mathrm{CBC}$, a blurb in Carleton University magazine and a hand written note from Carleton's president.

Both case studies came to a point where the participatory design came to a natural end and the design was handed back to the 'architect'. The big difference between the two 
groups was that in the Greely case, I was more proactive about contributing my design. When I felt the group was stuck on a generic solution, I took the design reins back in the interest of embodying the group's passion and direction for the project. With the Orleans group the decision for me to develop their design on my own and present it back to the group was made jointly with the group. They were satisfied with their effort and ready to hand it over.

In both cases I could have pushed further for more involvement such as another design workshop. However, I think that that would be an example of what Gina would say is volu-tolding, instead of volunteering. Participation in this capacity had to be $100 \%$ voluntary, and to push further I think would have been exerting my own will over the group. In both cases, the groups were happy with their contributions, trusted that their designs were in good hands and were ready to move to the next phase.

The Greely group process didn't follow the methodological script that I had so carefully adhered to with the Orleans group. There were many more meetings and design interactions that took place outside the group context, such as on the phone, internet or when a member couldn't make it to the meeting. This not only made it very difficult to monitor my own exertion of control but also for the group to be on the same page in the process.

Also the 'scope creep' of the project may have proved to be too much for three people. We started doing a small historical information booth and ending up designing a historic park complete with a larger information pavilion, sculptural element, toll gate replica, picnic area and parking. As the scope of the Greely project increased so did the involvement of other parties, and more complex relationships needed to be navigated; 
they were looking to reach beyond the community itself. The Orleans project also differed because the participants were their own target group, their own client. They wanted a place to gather in the shade, and yes generate more social connections, but they weren't looking to tackle a wider issue than that.

With Greely, what I had signed up for - to facilitate a design process - had turned into wearing many other hats; historical researcher, liaison with media, writer and now landscape or park designer. Though not part of my initial intent, I took on these roles because I wanted to see the project move forward.

What was interesting about both cases was that when I showed the group my model (Orleans was a sketch model, Greely's a quick SketchUp model) both groups really liked them. I was afraid that this would happen- and it did. I am not sure how to get around this. Perhaps showing them how to make a sketch model of a different project or other object would have the same instructional value, yet wouldn't interject my specific design.

Although I risked doing this by showing precedents that I had been involved in, the good ended up outweighing the bad. Being able to answer the group's questions regarding projects, and knowing the background story proved to breed a much deeper understanding and analysis of the precedent projects, and although the groups may have been influenced by the style, this influence did not seem to manifest itself overtly in the final design.

If I were to go back and do this project again, there are few things that I would change. One is that three participants are not enough. If one person can't make it, then there 
really isn't a'group' to collaborate with. Along this line, I would suggest that all meetings have at least three attendees- anything less than that and the meeting should be rescheduled. Also, I would suggest that designing should be kept in the design sessions; meaning that design related conversations via email, phone or one-on-one are better had when the whole group is involved.

Also, I really wish that I had made a better presentation at the Orleans Spring Annual General Meeting. Bringing some of the hardware was a good idea, but the graphic panels should have been larger and set up before people were arriving. It also would have been a great opportunity to 'gift' the participants as well, to thank them for their contributions and that I really enjoyed working with them. I will not miss the opportunity at the opening day festivities of the garden.

I knew that observing and facilitating would be difficult to do at the same time, hence the audio recording. However, video would definitely be more conducive to truly grasp what was going on. I know that it can be intimidating or uncomfortable for people, but to set up a discreet camera with high quality sound would have been more conducive to post observation. A lot of time was spent guessing who was talking and what they were talking about.

Though this thesis ends with one project fully assembled and scheduled build weekend coming up, and the other just about ready for the construction document phase, I think that the members of both groups would acknowledge that they had achieved real citizen power, the highest rungs on Arnsteins ladder, and as a result felt a strong sense of ownership of the project. I am looking forward to a post-occupancy evaluation and final critique from both groups to confirm this observation. 
Post thesis, I will be completing a publication for each group for their own personal use and for use as a teaching tool for other communities.

\subsection{Conclusion}

Looking back at the precedent research of Cardinal, Kroll, Hübner, Alexander, Mockbee and Alsop, there was no mention of any of the architects trying to hold off, or hold themselves back. Maybe this isn't something that has been included in documentation, or maybe it is a non-issue because it comes naturally for them to work this way. In my future collaborations I don't know that I will hold back as much as I did in the two case studies. I actually felt that my personality was being stifled at times, that I had to tiptoe around to be neutral. Alsop for example isn't stingy with praise or encouragement, and he doesn't come across at all as being self-conscious with controlling or not controlling the design. He values 'spontaneity, immediacy and vitality.'

One of my recurring nightmares from the beginning of this experiment has been that my collaborative case study projects would turn out to be ugly; that they wouldn't be attractive works of architecture; that my peers and professors would look down at them; the projects would certainly not be Architecture with a capital A.

Several things contributed to this inner conflict. One side of me was absolutely committed to the idea of following through no matter what (like Morgan Ip wished he had). The other side of me was terrified that the projects might turn out to look like Kroll's MéMé, a Frankenstein in my eyes. I felt a sense of responsibility to share the design and control process with each of the participant groups, but after reading quotes such as: "It is essential to keep your promise, however embarrassing to you the result may be."41 41 Design Methods, by John Chris Jones, xxxvii 
I wanted very much to take that control back but resisted the very real urge to succumb to tokenism and non-participation.

This brings me to my next un-conclusion. If the end-users like the project, feel proud of it, take ownership of it, care for it and it generates positive social change, then isn't that 'good architecture?' Does it matter that it doesn't get a photo spread in Architectural Digest or get a blip on a design blog? Mockbee's work doesn't have the typical pure, uninhabited, crisp feel that graces international magazines of architecture, and it certainly never appeared in any architectural texts or classes that I took in university, but the inhabitants are happy, they are invested and take ownership in what Mockebee calls "shelter for their souls." 42

The fact is that architectural quality is subjective - especially with respect to aesthetics. There are no guarantees that a user-led project will produce architecture with a capital A. Yet, there are also no guarantees - and plenty of examples - where even after decades of practice, professional architects can fail just as miserably. However, would I rather risk the aesthetic failure of a project knowing that it had the love of a community behind it? I honestly cannot answer this question $100 \%$ either way.

But I think back to a review session with Professor/Architect Paul Kariouk in which he said that lay people cannot see what we see; that most average people don't have imagination or spatial skills to project into the future something that isn't there, but could exist. I honestly never realised this before. I thought that everyone had this 'skill' to a certain degree; it was just a matter of how it much it was nurtured or exercised. In any event, the interesting thing was that through the increased participation of the groups I really felt an enhanced understanding of each project; that the participation provided a 42 Dean, Andrea Oppenheimer, and Timothy Hursley 7 
new way of communicating with the 'client.' I am not sure whether this occurred because I am a visual learner, or that the participants were able to really connect with the project and share things for which there would otherwise have been no forum. All along I was thinking that they would be the ones learning about architecture and the importance of good design, when in the end it was / who was really getting so much out of the process; this process perhaps provided a new way of seeing for the groups, but it was also a new way of listening for me.

I would also like to touch on one of the most unexpected outcomes of both case studies: basically how much fun the process was for me and the groups. I knew that I was enjoying myself and having a good time, but I wasn't aware of just how much fun we were having until I was transcribing the audio recordings of the meetings. Many parts of the transcripts are recorded as:

01:35:40-36 "Inaudible due to laughter."

Or

All: $\quad$ (giggling, laughing)

I don't think that filling out a survey or writing a brief could ever be this much fun.

A common thread amongst all of the architects that I studied was that they were fuelled by dissatisfaction with the traditional architectural process. Hübner, Kroll and Alexander felt that industry had over-standardized settings for living and lost the unscripted vitality of everyday life; they wanted to bring the human element back into architecture. Mockbee and Cardinal saw the process as exclusionary, that the answers to social ailments such as poverty and healing were found within the community, and that the typical top-down design process was ineffective and actually contributed to the 
problem. Arnsteins article was sparked by the same frustration that amongst the many claims of the 'power holders' true participation of the people to which these programs were supposed to serve was lost amongst 'understated euphemisms and exacerbated rhetoric $^{\prime 43}$

I am not sure what has fuelled my interest to explore a participatory methodology for architecture. Perhaps the disconnection I felt from the outside world during my university education? Or my belief that we are all born with a capacity for creativity, but that societal constructs undermine our confidence in that creativity? Or that $I$ am passionate about addressing social inequalities; that I have always rooted for the underdog? Perhaps it's just like Alsop says: "I like people. I hope it shows." ${ }^{44}$

Whatever the reason, I am certain that I will continue to practice along the lines of the participatory methodologies explored in this thesis. Working on this thesis has actually created a new vision of an architect in my head: "The Bridge." Basically, it is a person who has one foot in the profession and one foot in the everyday; balancing precariously to join the two worlds.

$43 \quad$ Arnstein 216

44 Title of a lecture that Alsop gave at The Sharpe East Center, Cambridge, 2008 


\subsection{Biblography}

Alexander, Christopher. The Oregon experiment. New York: Oxford UP, 1975.

Arnstein, S. R. "A ladder of citizen participation". Journal of the American Institute of Planners, Vol. 35, No. 4, July 1969, pp. 216-224.

Bell, Bryan. Good deeds, good design: Community service through architecture. New York: Princeton Architectural P, 2004.

Blundell Jones, Peter. "Human Hübner: The Steiner system of education offers many lessons to society in general. Peter Hübner crystallizes them." Architectural Review 1284 (2004): 44-51.

Blundell-Jones, Peter. Peter Hübner: Building as a social process. Stuttgart: Edition Axel Menges, 2003.

Dean, Andrea Oppenheimer, and Timothy Hursley. Proceed and be bold: Rural Studio after Samuel Mockbee. New York: Princeton Architectural P, 2005.

Dean, Andrea Oppenheimer. "AlA Gold Medal Winner: Samuel Mockbee." Architectural Record. The McGraw-Hill Companies, June 2004. Web. Sept. 2011. <http:// archrecord.construction.com/features/aiaAwards/04mockbee-2.asp >.

Ellin, Nan. "Participatory Architecture on the Parisian Periphery." Journal of Architectural Education. 53 (2000): 178-83.

Grant, Jill. The drama of democracy: Contention and dispute in community planning. Toronto: University of Toronto P, 1994.

Hill, Jonathan. "The Use of Architects." Urban Studies. 38.2 (2001): 351-65. Web. 30 Sept. 2011.

Ip, Morgan. Architecture and healing culturally appropriate design in the Canadian Arctic. Ottawa: Library and Archives Canada/Bibliothèque et Archives Canada, 2010.

Jenkins, Paul, and Leslie Forsyth. Architecture, participation and society. London: Routledge, 2010.

Jones, J. Christopher. Design methods. New York: Van Nostrand Reinhold, 1992. 
Kossak, Florian. Agency: Working with uncertain architectures. London: Routledge, 2010.

Kroll, Lucien, and Peter Blundell-Jones. An architecture of complexity. Cambridge, MA: MIT P, 1987.

Kroll, Lucien. "The Soft Zone." Architectural Association quarterly. 7 (1975): 48-59.

Milgrom, David. "16: Lucien Kroll." Space, difference, everyday life: Reading Henri Lefebvre. New York: Routledge, 2008. 264-81.

Moos, David, and Gail Andrews. Trechsel. Samuel Mockbee and the Rural Studio: Community architecture. Birmingham, Ala.: Birmingham Museum of Art, 2003.

Porter, Tom, and Will Alsop. Will Alsop:The noise. London: Routledge, 2010.

Shirvani, Hamid. The urban design process. New York: Van Nostrand Reinhold, 1985.

Till, Jeremy. Architecture depends. Cambridge, MA: MIT P, 2009. 
APPENDICES

\section{A) Email sent to Community Groups}

\section{Community Garden Groups:} Jardins Orleans Community Garden

Jardins Arrowsmith

Bethany Church Community Garden

Centertown Community Garden Project

Jardin Vanier Garden

Leslie Park Community Garden

Children's Garden at Robert Leggett Park

Rochester Heights Community Garden

Nanny Goat Hill Community Garden
Just Foods (urban farm/garden network)

The Bytowne Urban Gardens (BUGS)

Sandy Hill Community Garden

Sweet Willow Organic Community Garden

Go Green Community Garden

West Barrhaven Community Garden

Strathcona Heights Community Garden

Ottawa East Community Garden

\section{Collaborative Design Build Opportunity \\ messuge}

My name is Lee-Christine Bushey and I am a passionate about community building through architecture. I am currently a Carleton University thesis student, researching participatory/collaborative methodologies.

Your community garden contributes so much to the unity, health, beauty and liveliness of Ottawa. I would like to propose an opportunity to work together on the realization of an architectural project of your choice.

My role would be to facilitate the process from conception to completion. Questions of scale, budget, time, materiality, permanence, methodology, and design will be discussed. We will start by discussing what we love about the garden, what we think could be improved and how architecture could respond. For example, the garden is flourishing with acthity, but there isn't a place to sit back and relax, a place to take time to stop and smell the roses! This is just a theoretical example- the project will be in response to the unique needs of the group.

The only requirement to participate... is a desire to participate! Amyone who will be using the final project is encouraged to participate. Special skills or knowledge are not required.

I hope that you are interested in this idea (or know a group that might be) and would allow me to present this opportunity to you. Please contact me at your comenience.

Sincerely, Lee-Christine Bushey

"Participatory Architecture is an architecture that enables and encourages active participation of the users of a system with the goal of instilling a sense of community among the users." 
A) Cont...

\section{Community Associations}

Civic Hospital Neighborhood Association.

Greely Community Association

Centertown Citizens Ottawa Corporation

Vars Community Association

Hintonburg Community Association
Glebe Community. Association.

Fairlea Community Association

Old Ottawa South Community Association

Woodroffe North Community Association

Osgoode Community Association

Collaborative Design Build Opportunity

Lee-Chritine Bushey

Mon, Sep 26, 2011 at 9:51 P

Dear President and all Members -

My name is Leo-Christine Bushey and I am a passionate community achocate. I am currently an architecture thesis student at Carleton University, researching participatory/collaborative methodologies. I have also worked for 6 years in a local architecture firm.

Your association has always contributed so much to the unity, health and liveliness of our neighbourhood. I would like to propose an opportunity to work together on the realisation of an architectural project of your choice.

My role would be to facilitate the process from conception to completion. Questions of scale, budget, timing. material, methodology, and design will be discussed. An example project would be an outdoor shade pavilion; however, the type of project would be totally up to the unique needs of the group. Basically, the question is: How can architecture respond to a need or desire within the community?

The only requirement to participate... is a desire to participatel Anyone who will be using the final project is encouraged to participate. Special skills or knowledge are not required.

I hope that you are interested in this idea (or know a group that might be) and would allow me to present this opportunity to your group. Please contact me at your convenience.

Sincerely,

Lee-Christine Bushey

"Participatory Architecture is an architecture that enables and encourages active participation of the users of a system with the goal of instilling a sense of community among the users." 


\section{B) Group Handout}

\section{COLLABORATIVE DESIGN-BUILD OPPORTUNITY}

Lee-Christine Bushey,

Thesis student at Carleton University: Participatory Architecture.

OBJECTIVE: is to collaborate with a group to design and build a project that will address/ improve an aspect of the community that the group identifies as important, and that has best chance of reaching substantial completion by March 2012. At this point I am looking for a group to work with. I am meeting with 7 different groups until Oct. 19th, and then will hopefully secure a commitment with one group to move forward. My goal is to find the best match possible in terms of finding a project that is most likely to come to fruition.

\section{METHODOLOGY:}

WORKSHOP 1: Community Inventory (min. 3 people 2 hours)

-go over previously gathered information, site visit, identify positives/negatives -what do we love about the community? What is lacking?

WORKSHOP 2: Design (min. 3 people 2 hours)

-brainstorm solutions (of the built kind) and compare to community inventory

-selection of 2-3 projects, design process activities (geared to group)

-identify constraints and guidelines (materiality, time, scale, funds, permits, permissions) -identify individual tasks (i.e. material donations)

WORKSHOP 3: Design II (min. 3 people 2 hours)

-finalize project selection; refine design responding to constraints/guidelines

-identify individual tasks (i.e. scheduling, lee drawing blueprints)

WORKSHOP 4: BUILD! (min. 3 people 4 hours) plus able bodies!

-site prep and build...

-celebrate!

What could this look like?: A neighbourhood group identified that connecting with nature and socialization were lacking in their community. There was a community garden but it only served the 3-4 gardeners in the neighbourhood. They determined that a shade pavilion with seating could invite non-gardeners to gather, a place to have a picnic or read a book. The materials used were: rammed earth, lumber (leftover from a deck renovation) hardware and concrete were donated from the local building supply store. No permits were required because the land belonged to the adjacent church, and the pavilion was less than $100 \mathrm{ft} 2$. There were 5 participants who spent 2 Wednesday nights (in the church basement) designing, and 2 Saturdays building on site. Each individual spent 1-2 hours of their own time gathering supplies, or tools, or making invites for the 'opening' etc. 
Additional notes:

- Participation/collaboration?

- Architectural vs. artistic project

- Documentation, (preview before publishing)

- follow up, post-occupancy, measure success?

- Guarantees?

- Timeline? Substantial completion by March 2012

Thank you!

Lee-Christine Bushey, B.Arch

\section{C) Community Association Meeting Summaries}

\section{a. Fairlea Community Association}

The first reply came the evening that I sent the email. Dr. Peter Stockdale had been the chair of the Fairlea Community Association for 15 years, and a resident for 23 . He said that he called right away because he knew that I would be receiving a lot of interest. He has a history of community action projects and interest in participatory methodologies as well. He was involved in the nearby Albion-Hetherington Community Centre project that involved at lot of consultation with residents and he feels was quite successful. The adjacent playground was achieved through a funding award from INGDirect and Bienenstalk Natural Playgrounds wherein the residents helped design and build the project. He feels that this project was also successful, especially in one of the 'rougher' neighbourhoods in Ottawa, he feels that the community involvement has warded off vandalism to the park.

There have recently been several community consultations involving door-to-door surveys through a partnership with the Boys and Girls Club and the Ottawa Police Force. There was a strong desire for more recreational facilities. The playing fields are regularly booked by league teams instead of locals, the new community centre is too far (>1 km) and there are a lack of informal areas to socialize. Benches, bleachers or a gazebo would free up the play structures for children and tots which are now being used as hangout spots for teens.

On the logistics side of the possibility of working with Fairlea, Dr. Stockdale was concerned about my short timeline, especially if the City of Ottawa was involved. We brainstormed ideas to get around working with the City, or as little as possible. One idea was renovating the existing skate shack. It is only used in the winter, and sits locked up in 
the middle of the field the rest of the year. Perhaps this structure could be altered to act as a shade pavilion in the summer? I learned that if the city is responsible for a structure then they are also responsible for the onsite safety of participants and maintenance as well. What about land that doesn't belong to the City? There was a nearby co-op that did have communal land and even a small clubhouse, however, they were separate from the Fairlea community association and he didn't think that they would be interested.

\section{b. Civic Hospital Area Parks and Recreation Committee, Reid Park Project}

The Reid Park Project is a renovation of the existing park; it includes a lawn bowling club and green, a past-the-point-of-repair farm house (the Reid Farmhouse) a snow dump area for the city and an informal dog park; it is bound on three sides by upscale single family homes and the Queen's Way on the north side.

Kate Harrigan is a very active retiree who is heading up this project and several others for the betterment of her community. The group is rallying for a new community centre at the park that would include space for fitness classes, meeting rooms, and after school programs. She discovered these needs by issuing an online community survey that received about 100 responses. The other issues are the access to the park, the overlap of dog park with playground, and lack of infrastructure such as benches, picnic tables etc. This is where Kate thought that we could work together on. She said the community centre is going to be a typical 'template' building by the city but perhaps the new gazebo could be a collaborative community design/build. Again, if the City was involved though, making the spring deadline was questionable.

What would have been ideal for the group is for someone to head up this project; to work with the City to make this project happen for the community. Someone who could pull together all of the aspects that make a project like this happen; to manage issues relating to: funding, design, permits, politics, grants, community support, the construction process, from start to end basically. I am realizing that people who volunteer seem to always be looking for volunteers, because they are always... volunteering.

\section{c. Glebe Community Association Tot Lot Project}

The North-East Glebe Park Committee did an inventory of their parks and decided that they needed a tot friendly park. There were other parks but were not suitable for tots and toddlers. The place that they identified for the tot lot was a traffic island that it being converted to corner lot by the city in the future due to water infrastructure upgrades. The lot is $3 / 4$ city property and $1 / 4$ NCC property. The lot was deemed just the right size and would otherwise be underused, that their was a retirement home within short walking distance who's residents expressed interest in visiting the park. The Ottawa cycling group who also had a vested interest in the 'renovation' of the lot would have to be consulted as well, since their existing path cuts thru the site. Since the city would be tearing up a portion of the lot to do water line upgrades, the group thought that it 
would be good timing to add a fountain that the bikers could use too.

I was asked to present my thesis idea at the committee meeting, but unfortunately I was already booked to go to Greely. However, Elizabeth was able to co-ordinate another meeting on short notice on the Friday with a few of the group's members to talk solely about the tot-lot project. We met at Elizabeth's house in the Glebe; there were 4 attendees from the neighborhood: A retired engineer, a new mother and baby, 2 female retirees, one of which was the host. All had lived in the glebe for 10-20 years, except the new mom and baby, who had moved there within the last 2 years.

The group was very excited to share their thoughts about the project; the obstacles, their experience with the project thus far, and how they thought that I could help. The group was looking for someone to champion the project; someone who would navigate and liaise with the City, the NCC, and the adjacent TD Bank; to go through the paperwork, attend meetings, make this project happen. To attend city hall meetings, zoning reviews etc. To do the drawings, secure funding, apply for grants, fundraise, public awareness and support.

One member spoke up to say that it wasn't fair to ask me to do that part of the project, and I conceded that I wasn't a politician or had any experience with these processes, and that that wasn't what my thesis was investigating. Not that I am not interested in that part of the process of 'community architecture' but I with a thesis, ending in 5 months I needed to keep my scope focused.

By the end of the meeting it was clear that my thesis investigation and guidelines were not matching up with what the group needed/wanted. We brainstormed how and if there was a way to bridge the disconnect. For example, could we design and build a model together, or a portion of the project, such as a bench? Would this satisfy my thesis requirements? I said that I would talk to my thesis advisor about these ideas, and try to come up with a solution that would satisfy both parties.

However, after the meeting I revisited the proposed site and began to realize that had mixed feelings about taking on the project. I think that a tot lot would be great addition to the neighborhood and it is an area of architecture that I am very interested in. However, the group was set on a location that I felt compromised the safety and of those that would be going there- children and seniors. The group had done their research and that was the best spot in their quadrant, but It didn't sit well with me. I know that through good design, safety can be ensured within the small park itself, but it was all the crossing of traffic, busy parking lots and bike lanes that I felt were a larger risk. I didn't feel that I could support them in their decision to erect a park in this specific spot. 
G) Orleans Community Garden Build Day 1
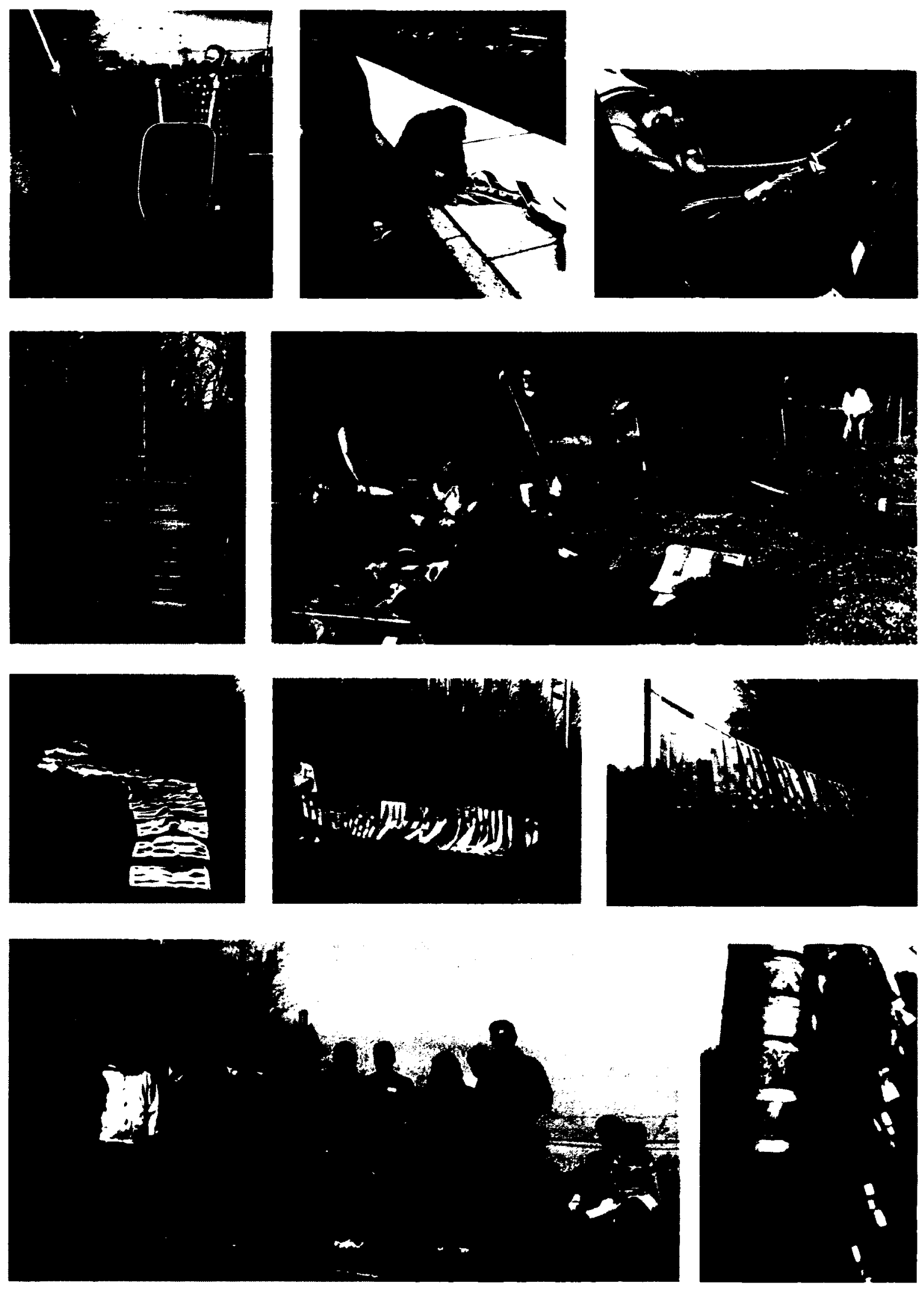